\title{
1 Grain Size and Beach Face Slope on Paraglacial Beaches of New England, USA
}

3 Authors: Jonathan D. Woodruff ${ }^{1}$, Nicholas Venti ${ }^{1}$, Stephen Mabee $^{2}$, Alycia DiTroia ${ }^{1}$, Douglas

4 Beach $^{1}$

5

6 Affiliations:

$7 \quad{ }^{1}$ Department of Geosciences, University of Massachusetts, Amherst, MA 01003, USA

$8 \quad{ }^{2}$ Massachusetts Geological Survey, Amherst, MA 01003, USA

9

10 Corresponding author: Jonathan D. Woodruff (woodruff@umass.edu)

11

12 Keywords: Beach processes, Glacial sediments, Mixed-sand-and-gravel, Mesotidal, Microtidal,

13 Bimodal

14

15 Highlights:

16 - New England is an important region with mixed sand and gravel (MSG) beaches

17 - Grain sizes are controlled primarily by glacial-fluvial and till sediment sources

18 - Beaches have bimodal grain size distributions inherited from paraglacial deposits

19 - Sand characteristics are the primary governor of MSG beach face slopes 


\section{Abstract:}

23 Approximately 100 paired summer and winter transects of beach face slope and intertidal grain

24 size were examined from 18 separate beaches in southern New England that span meso- and

25 micro- tidal regimes. Paraglacial materials provide the principal local sediment source to beaches

26 in this region and grain-size distribution of beaches corresponds to adjacent surficial geology.

27 Stratified glacial fluvial deposits are the primary sediment source to sandier beaches, while till

28 predominantly source the coarser gravel-dominated systems. When aggregated, grain size

29 measurements exhibit a bimodal distribution of medium-to-very-coarse sand (0.25-to- $1 \mathrm{~mm})$ and

30 medium-to-very-coarse gravel (10-to-64 mm), with a paucity of grains between 1-10 $\mathrm{mm}$. This

31 bimodality is also common to and likely inherited from the glacial fluvial deposits sourcing the

32 beaches. Beach face slope is observed to increase with median grain size $\left(\mathrm{D}_{50}\right)$ for finer sandy

33 systems, followed by little-to-no correlation for coarser mixed sand-and-gravel beaches where

34 bulk $\mathrm{D}_{50}$ is greater than $\sim 1 \mathrm{~mm}$. This finding is consistent with previous trends observed in 35 global beach data sets and highlights the limits of using bulk $\mathrm{D}_{50}$ to describe bimodal systems.

36 When gravel is removed from the grain size distribution and the median grain size recomputed

37 for the remaining sand fraction the familiar positive relationship between grain size and slope

38 reemerges. Results support the growing appreciation for sand characteristics as the primary

39 governor of intertidal slope for mixed sand and gravel systems due to its predominant control on 40 beach face permeability and resulting transport processes. 


\section{1. Introduction}

43 Beaches comprise approximately $31 \%$ of the world ice free shoreline (Luijendijk et al., 2018),

44 and serve a multitude of functions including a diverse array of ecological services, key forms of

45 flood defense, and prized locations of recreation and revenue (Martínez et al., 2007). These

46 sedimentary systems are some of the most dynamic landforms on earth and are influenced by a

47 variety of factors that involve waves and tides (e.g. Ivamy and Kench, 2006; Masselink and

48 Short, 1993; Shulmeister and Kirk, 1997), sedimentary supply, sea level change and antecedent

49 conditions (e.g. Billy et al., 2015; Carter et al., 1989; Fitzgerald and Van Heteren, 1999; Forbes

50 et al., 1995a; Kirk, 1980; McLean and Kirk, 1969; Orford et al., 2002), and anthropogenic

51 modifications (e.g. Hein et al., 2019; Horn and Walton, 2007).

52

53 Beach slope and grain size are defining features of beach morphology and the factors that

54 controls these two properties have long been an area of active research. The World War II Waves

55 Project along the Pacific Coast of North America represents an early seminal study on this topic

56 (Bascom, 1951). Five tenets of beach morphodynamics emerged from the project: 1) that the

57 intertidal zones of fine sandy beaches are flatter than those of coarse sandy beaches, 2) that

58 beach material at any place is well sorted, 3) that this sorting occurs by facies, with plunge point

59 (where wave uprush and backwash intersect) being coarsest, followed by the beach berm, the

60 intertidal zone, dune sand, and finally the finest material found with increasing depth off-shore,

61 4) that beaches build seaward and steepen under gently sloping waves and are cut back and

62 flattened by steep waves, and, 5) that wave exposure sorts material into appropriate

63 environments along the coast. The seminal Bascom (1951) paper restricts its scope to sandy

64 beaches, leaving the gravelly beaches for later discussion. 
66 Subsequent research on coarser beaches indicate that they do not predictably follow the five

67 patterns Bascom (1951) identifies in sandy systems. Regarding the slope/grain size relationship

68 (1), flatter slopes are not always associated with finer grain sizes (McLean and Kirk, 1969) and

69 gravelly beach faces plateau in slope before becoming steeper than sandy beaches as sand

70 becomes excluded from the beach in coarser systems (e.g. Bujan et al., 2019). With respect to

71 sorting (2), on some of these coarser beaches, gravel and sand are well mixed throughout while

72 others follow a composite character with well sorted cobble and gravel in upper facies and well-

73 sorted sand in their intertidal zones (e.g. Bluck, 1967; Jennings and Shulmeister, 2002). Thus,

74 not only are these systems not necessarily well sorted by facies, the facies themselves follow

75 more than one distribution, defying the ranking of faces by sort (3). Regarding wave state and

76 cross-shore morphology described in 4, rather than predictable advance or retreat in response to a

77 dynamic wave regime, sand and gravel beaches instead often undergo various degrees of sorting

78 (Pontee et al., 2004). Finally, with respect to alongshore variability described in 5, instead of

79 materials well sorted into environments along the coast according to wave energy, sediment

80 sources and coastal barriers often bias (and in many cases predominantly control) the type and

81 size of materials appearing on sand and gravel beaches (Fitzgerald and Van Heteren, 1999;

82 McLean and Kirk, 1969).

83

84 Several classification systems for sand and gravel beach systems exist (e.g. Bluck, 1967;

85 Caldwell and Williams, 1985; Carter and Orford, 1993; Jennings and Shulmeister, 2002). Carter

86 and Orford (1993) offer a two-part classification for coarse clastic shorelines consisting of

87 beaches as free-standing or fringing barriers. These are further subdivided into swash or drift- 


\section{EarthArXiv preprint under review in Marine Geology}

88 aligned beaches. For Southern New England, USA, FitzGerald and Van Heteren (Fitzgerald and

89 Van Heteren, 1999) define six coastline types based on several parameters including geology,

90 antecedent topography, sediment availability, grain size and wave and tidal energy. This

91 classification system incorporates geomorphology and indirectly includes sediment sourcing as a

92 factor in beach characterization. Jennings and Schulmeister (2002) examine 42 gravel beach sites

93 in New Zealand and develop a three-part classification: 1) pure gravel, 2) mixed sand and gravel

94 (MSG) and 3) composite beaches of steeper upper-intertidal gravel and gently sloping lower-

95 intertidal sands. Horn and Walton (2007) later suggested a $4^{\text {th }}$ beach type where a steeper upper

96 beach is composed of MSG and a lower-tide terrace of sand.

98 Predominant regions with detailed studies on MSG systems include the alluvial/fluvial and

99 hinterland sourced beaches of southern New Zealand (e.g. Kirk, 1980; McLean and Kirk, 1969;

100 Shulmeister and Kirk, 1997), as well as the paraglacial shorelines (Forbes and Syvitski, 1994) of

101 the British Isles (Carter et al., 1987; Jennings and Smyth, 1990; Mason and Coates, 2001; Pontee

102 et al., 2004), and eastern Canada (Carter and Orford, 1993; Forbes et al., 1995). The

103 Northeastern coast of United States from the United States/Canadian border south through New

104 York state represents another paraglacial coastline where MSG beaches are prevalent. Studies

105 along this $\sim 13,000 \mathrm{~km}$ stretch of coast provide detailed insight on its geomorphic evolution and

106 response to past changes in relative sea level and sediment supply (e.g. Fitzgerald and Van

107 Heteren, 1999; Hein et al., 2014; Kelley, 1987), yet still lacks a regional analyses on grain size

108 and beach slope characteristics. For example, of the 2144 measurements of beach slope and grain

109 size synthesized in a recent global compilation focused to MSG systems (Bujan et al., 2019), no

110 data is available for the Northeastern US. 
112 This study is focused to grain size and intertidal slope measurements from beaches of

113 Massachusetts, which represents a particularly unique section of the Northeastern US coast in

114 that it: 1) lies at the interface between New England's paraglacial lowlands and Mid-Atlantic

115 Coastal Plain (Fenneman, 1938), 2) spans both micro- and meso- tidal regimes (Redfield, 1980),

116 3) encompasses a wide range of seasonally varying wave conditions (Woolf et al., 2002), and 4)

117 contains a diverse array of geomorphic and grain size characteristics (Fitzgerald and Van

118 Heteren, 1999).

120 2. Regional setting

121 The study area extends along the entire coast of Massachusetts. Prominent coastal features for

122 this region, from north to south, include the mouth of the Merrimack River, Cape Ann,

123 Massachusetts Bay, Cape Cod and associated islands of Martha's Vineyard and Nantucket, and

124 Buzzards Bay (Fig. 1). During the last glaciation, the region was located near the southern extent

125 of the ice sheet on the uplifted glacial forebulge. The continued relaxation of this forebulge has

126 amounted to $\sim 0.7-1.0 \mathrm{~mm} / \mathrm{yr}$ of subsidence over the last few millennia (Engelhart and Horton,

127 2012; Peltier, 2004). However, at mean rates of $2.0 \mathrm{~mm} / \mathrm{yr}$ (Portsmouth, $\mathrm{NH}$ ) to $3.8 \mathrm{~mm} / \mathrm{yr}$

128 (Nantucket, MA) over the past century, sea level rise in the northeastern U.S. (Zervas, 2009)

129 eclipses gentle postglacial isostatic adjustment by nearly 2-to-5 times.

131 Cretaceous (and Cenozoic) sediments underlie the glacially derived and postglacial material of

132 Cape Cod and the islands to the south in Massachusetts (Finch, 1823; Oldale and Barlow, 1986;

133 Stone et al., 2018). This area was initially considered part of the New England Physiographic 


\section{EarthArXiv preprint under review in Marine Geology}

134 region (Fenneman, 1917, 1916), because here Cretaceous (and Cenozoic) coastal plain sediments

135 lie largely below sea level, whereas this sequence would be extensively exposed further to the

136 south on Long Island in New York State, if it were not covered by post-glacial materials.

137 However, revised geographic interpretation recognizes this area as the northeastern most

138 (exposed) extension of the Atlantic Coastal Plain as it emerges from the continental shelf

139 (DiPietro, 2012; Fenneman, 1938; U.S. National Park Service, 2017). Provenance of sand on the

140 eastern part of Cape Cod supports a significant reworked coastal plain component in material

141 along the coast in this region (Ockay and Hubert, 1996).

142

143 Most of the surficial sediments in New England, including Massachusetts, were deposited during

144 past glaciations in the late Pleistocene (Fig. 1), and largely define the sources of sediment to

145 individual beach systems. Glacial sediments are unevenly distributed over the landscape in New

146 England, resulting in a regional coastline that is generally sediment starved relative to other

147 regions of the U.S. (Fitzgerald and Van Heteren, 1999). However, sediment sources can

148 generally be categorized into three groups (Table 1): 1) stratified deposits - this includes subsets

149 of both, 1a) coarse stratified deposits derived from glacial outwash or kame and river deltas and,

150 1b) fine stratified deposits originating from the erosion of fine-grained glacial marine sediments;

151 2) glacial till; and, 3) mixed sediments consisting of material derived from stratified deposits and

152 glacial till in various proportions.

153

154 Tidal ranges vary depending on location. North of Cape Cod extending to the north shore of

155 Massachusetts the tidal range is roughly $3 \mathrm{~m}$ (Table 1). South of Cape Cod the tidal range is

156 approximately $1 \mathrm{~m}$ or less (Irish and Signell, 1992; Redfield, 1980). Based on the categorization

157 system of Hayes (1979) study beaches north of Cape Cod are predominantly tide-dominated and 
158 beaches south of Cape Cod are classified as wave-dominated (Fitzgerald and Van Heteren,

159 1999). This is with the exception of the more southerly exposed beach at Rockport that is north

160 of Cape Cod but which is a mixed tide-wave energy system (DiTroia, 2019).

162 Eighteen beaches were investigated in this study (Fig. 1) and fall into three main geomorphic

163 classes according to the scheme developed by FitzGerald and Van Heteren (1999) for paraglacial

164 barrier beach systems (Table 1; DiTroia, 2019). Salisbury and Plum Island on the north shore of

165 Massachusetts are inlet-segmented (Type 4) beaches composed of long single barrier beaches

166 separated by inlets with significant updrift, river, or offshore glacial fluvial sediment sources.

167 Rockport, Nahant, Revere, Nantasket, Peggotty, Humarock, Marshfield, Barges, East and

168 Horseneck are all headland-separated (Type 2) beaches composed of shorter, narrower barriers

169 separated by bedrock or till headlands providing local, variably sized but less reliable sources of

170 sediment. The remaining beaches, Plymouth, Surf, Low, Miacomet, Town and Sylvia are

171 mainland-segmented (Type 3) beaches comprised dominantly of sand or sand with some gravel

172 derived from glacial outwash and mixed sediment sources (till and outwash), respectively.

\section{2.1. Sediment sources for beaches north of Cape Cod}

175 Beginning at the northern extent of the study area, Salisbury and Plum Island beaches represent

176 two systems sourced predominantly from relic fluvial deltaic deposits. The Boston area and

177 north shore of Massachusetts underwent a marine incursion during initial ice retreat followed

178 closely by isostatic rebound that produced a rapid relative sea level drop allowing the post-

179 glacial Merrimack River to deposit a veneer of fluvial sediments and an offshore delta (Fig. 1),

180 (Barnhardt et al., 2010; Oldale et al., 1993; Stone et al., 2006). Delta foreset beds overlying

181 marine silts and clays are evident in offshore seismic records (Barnhardt et al., 2009). Holocene 


\section{EarthArXiv preprint under review in Marine Geology}

182 marine transgression reworked the delta and fluvial deposits providing the primary source for 183 sediments along with riverine contributions from the adjacent Merrimack River.

185 The Rockport site, known locally as Long Beach, is located just south of Salisbury and Plum 186 Island on the rocky peninsula of Cape Ann. Of all the sites, the sediment source for Rockport is 187 one of the most difficult to assess. The beach is located in an area of numerous granite bedrock 188 outcrops interspersed with pockets of very thin glacial till $(<1-2 \mathrm{~m})$ (Stone et al., 2006). The 189 Rockport site is enclosed on each end by two bedrock headlands and comprised mostly of 190 medium sand at low and mid tide but underlying cobbles and gravel are exposed at high tide in

191 the winter. There is a marsh/swamp located behind the beach. During Holocene marine

192 transgression it is likely marsh/swamp deposits were much farther seaward and the beach

193 transgressed over the deposits as it migrated shoreward during sea level rise (Emery et al., 1967).

195 The Nahant site and Revere Beach are both sourced by fine-grained stratified deposits (Table 1)

196 that underlie later post-glacial deposits throughout the Boston area (Fig. 1) (Stone et al., 2018).

197 These fine-grained deposits are marine silts and clays deposited prior to ice retreat when relative 198 sea level was 31 to 33 m higher than modern sea level (Stone et al., 2004b). It should be noted 199 that Revere underwent major restoration in the 1990s and is nourished annually with up to 10 200 tons of fine sand to support a sandcastle building contest during the summer. Nahant also 201 underwent a dune restoration project in 2014.

202

203 Nantasket Beach, located immediately south of Boston is adjacent to several till-based drumlins, 204 including some eroded offshore, that served as the main source of sediment to the beach (Fig. 1). 
205 However, it was common practice to remove the gravel armor that appeared after each winter,

206 resulting in a lowering of the beach profile over time (FitzGerald and Rosen, 1988). This may

207 have skewed its grain size to become somewhat finer than would otherwise be expected from a

208 glacial till source. It is estimated that $96,000 \mathrm{~m}^{3}$ of cobbles and gravel were removed from the

209 beach between 1950 and 1968 by beach maintenance crews (USACE, 2012).

211 Along the south shore of Massachusetts Bay, Peggotty, Humarock and Marshfield beaches are

212 mixed beaches receiving sediment from the erosion of both coarse stratified deposits (glacial

213 outwash) and glacial till (Table 1; Fig. 1) (Stone et al., 2018). The Plymouth site is located to the

214 south of Marshfield and lies adjacent to an extensive, glacial outwash deposit characterized by

215 very hummocky, kame and kettle terrain (Fig. 1) (Stone et al., 2012).

\section{2.2. Sediment sources for beaches south of Cape Cod}

219 Miacomet and Low Beaches are located on the island of Nantucket. Similar to Plymouth,

220 Miacomet and Low are also sourced from glacial outwash (Fig. 1), but are located approximately

$2214 \mathrm{~km}$ from the late Wisconsinan terminal moraine whereas the glacial outwash deposits near

222 Plymouth represent a more distal and finer facies of the outwash morphosequence (Koteff and

223 Pessl, 1981; Stone et al., 2004a).

225 Surf Beach, located on the south side of Cape Cod (Fig. 1), is situated just east of the contact 226 between the Buzzards Bay recessional moraine and the "Crooked Pond deposits". The Crooked

227 Pond deposits are near-ice-marginal glaciofluvial fan deposits onlapping the Buzzards Bay

228 moraine and eventually overlying the distal end of pitted outwash plains to the east (Stone and 


\section{EarthArXiv preprint under review in Marine Geology}

229 Stone, 2019). These deposits contain cobbles and gravel and were noted as the "very coarse-

230 grained Mashpee pitted plain deposits" recognized by Mather et al. (1942) and Masterson et al.

231 (1997) but not previously mapped (Stone and Stone, 2019).

232

233 Town and Sylvia Beaches are located on the island of Martha's Vineyard (Fig. 1) and are

234 comprised of sediment from a mixture of two surficial deposits, till associated with the late-

235 Wisconsin terminal moraine and glacial outwash. The terminal moraine deposits are comprised

236 mostly of boulders and sandy till (Stone and DiGiacomo-Cohen, 2006). Town Beach is sourced

237 primarily from sandy till but there is a veneer of outwash overlying the till deposits (Oldale and

238 Barlow, 1986). At Sylvia Beach, the terminal moraine is buried by thicker deposits of outwash.

239 Accordingly, Sylvia Beach is sourced by a higher proportion of outwash than Town Beach,

240 which contains a higher gravel/cobble component.

242 To the west of Martha's Vineyard lies the Elizabeth Island chain, formed from the Buzzards Bay

243 recessional moraine. Barges Beach is located on Cuttyhunk, the southwesternmost island of the

244 Elizabeth Islands, and is composed mostly of gravel and cobbles derived by the erosion of the

245 recessional moraine (Fig. 1). Finally, Horseneck and East Beaches lie to the west of Buzzards

246 Bay, along the westernmost portion of mainland Massachusetts bordering the State of Rhode

247 Island, and are sourced by the direct erosion of glacial till in widely distributed ground moraines 248 (Fig. 1).

\section{3. Materials and methods}

251 Beaches in this study were selected in collaboration with the Massachusetts Office of Coastal

252 Zone Management in order to characterize the grain size distribution and beach slope in the 


\section{EarthArXiv preprint under review in Marine Geology}

253 intertidal zone. Between 2 and 10 intertidal transects were conducted for each of the sites

254 depending on the length of the beach and accessibility. Transect positions were chosen at

255 representative locations along the beach and equally spaced when possible. At each transect at

256 least three separate samples were collected at near 1) high-tide, 2) mid-tide and 3) low-tide.

257 When possible, additional samples were collected along storm berms and dunes but for brevity

258 are not presented here. To assess seasonal variations in grain size distribution and slope, all

259 transects along beaches were sampled and surveyed twice, once at the end of the summer and

260 then revisited again at the end of the winter season. Surface sediments from the top 15-30 cm

261 were collected from sites primarily composed of sand and pebbles (i.e. $<64 \mathrm{~mm}$ ), and brought

262 back to the University of Massachusetts in Amherst, MA for analysis. Exclusively sand samples

263 were collected in 1-liter (1-quart) bags, predominantly sand samples were collected in 4-liter (1-

264 gallon) bags and mixed sand and pebble samples in 19 -liter (5 gallon) buckets. Areas comprised

265 primarily of cobbles and boulder $(>64 \mathrm{~mm})$ were measured in the field using a gravelometer and 266 standard pebble count techniques (Wolman, 1954).

267

268 Sediment samples were washed and dried thoroughly to remove salt and debris (sticks, seaweed,

269 etc.). Each sample was weighed and sub-divided into fractions greater and less than $4 \mathrm{~mm}$.

270 Distributions for grains greater than $4 \mathrm{~mm}$ were obtained via standard sieving techniques

271 (Udden, 1914; Wentworth, 1922)(Udden, 1914; Wentworth, 1922). Grain size distributions for

272 sample fractions $<4 \mathrm{~mm}$ were measured on a CAMSIZER digital particle size analyzer capable

273 of measuring particles between $30 \mu \mathrm{m}$ and $4 \mathrm{~mm}$ (Switzer and Pile, 2015). A total of 907 grain

274 size analyses and 86 pebble counts were conducted (See Section 7 for data availability).

275 
276 Inter-tidal beach slope for each transect was obtained using a using a Real Time Kinematic

277 (RTK) GPS survey system or a total station survey system tied to local benchmarks. Markers

278 were placed at the head of each transect so the transects could be reoccupied the following

279 season. A total of 235 transects were completed.

281 Off-shore wave conditions were independently reconstructed for each beach based on publicly

282 available results from the United States Geological Survey (USGS) Coupled Ocean-

283 Atmospheric-Wave-Sediment Transport (COAWST) model (Warner and others, 2010), and

284 using the nearest deep-water grid cell to each respective beach. Modeled average wave heights

285 directly off-shore of the sites in the 30-days preceding seasonal surveys ranged between $0.4 \mathrm{~m}$

286 and $2.5 \mathrm{~m}$ (bars in Fig. 2A), with storm-induced 12-hr -averaged maxima over the same intervals

287 between $0.9 \mathrm{~m}$ and $7.6 \mathrm{~m}$ (circles in Fig. 2A). North of Cape Cod modeled wave heights were

288 largest overall for Rockport Beach, which is south facing and located on the prominent rocky

289 exposed headland of Cape Ann (Fig. 1). South of Cape Cod the southern facing beaches of Low

290 and Miacomet on Nantucket were the largest. Smallest wave heights south of Cape Cod were

291 modeled for the nearby beaches of Sylvia and Town, located on the northeast coast of Martha's

292 Vineyard facing back to the Cape Cod mainland.

293

294 In terms of seasonality, modeled winter wave heights were consistently higher than summer at

295 all sites (Fig. 2A), with the more exposed shorelines experiencing the greatest increases overall

296 (e.g., an increase in 12-hr-averaged max wave heights between summer and winter of $>5 \mathrm{~m}$ at

297 Rockport and 2-to-3 m for Low and Miacomet). In contrast, minimal seasonal differences in 
298 wave height occurred at more sheltered sites including the northeast facing Martha's Vineyard

299 beaches of Sylvia and Town, where winter increases did not exceed a few $\mathrm{cm}$.

301 4. Results

$302 \quad 4.1$ Regional and seasonal changes in grain size and beach face slope

303 For summer surveys a regional median grain size of $0.8 \mathrm{~mm}$ was observed south of Cape Cod 304 and $0.4 \mathrm{~mm}$ for the north (Fig 2B). These regional medians increased in the winter surveys to 1.2 $305 \mathrm{~mm}$ for the south and $0.6 \mathrm{~mm}$ for the north. Grain sizes were therefore greater where wave 306 heights were higher south of Cape Cod and during the season of greater wave activity. However, 307 these regional differences were less that the overall variance observed in grain size distributions 308 from site to site, which ranged by an order of magnitude, and reveal the diverse types of sandy to 309 MSG beaches evident in both tidal regions. Seasonally, grain size distributions coarsened most 310 significantly in the winter for MSG systems (e.g. Pegotty, Humarock, Town, Surf, Barges, East 311 and Horseneck), due in part to an apparent winnowing of sands from these locations. Sandier 312 systems also tended to coarsen in the winter, although less significantly than at MSG locations, 313 and with the exception of Nahant and Plymouth, where a slight winter fining was observed.

315 Active beach slopes of mesotidal beaches north of Cape Cod were predominantly flatter than 316 microtidal sites to the south (Fig. $2 \mathrm{C}$; slope medians of $\sim 0.06$ and $\sim 0.12$ for meso- and macro317 tidal regions, respectfully). This finding is consistent with past observations of beach widths 318 generally increasing with increasing tidal range (e.g. Masselink and Short, 1993). However, 319 similar to grain size, intertidal slopes for individual beaches varied greatly relative to these 320 regional medians, and did not necessarily correlate with bulk grain size. For example, beach face 


\section{EarthArXiv preprint under review in Marine Geology}

321 slopes at the meso-tidal and predominantly sandy Plum Island site were similar or steeper than a

322 majority of slopes for coarser MSG systems at microtidal locations (e.g. Town, Surf, Barges and

323 Horseneck). The steepest beaches observed in the study were during summer at the

324 predominantly sandy Low Beach and during winter at the MSG East Beach. Although

325 predominantly sandy, the steeper Plum Island and Low Beaches did exhibit some of the coarsest

326 sand fractions of meso- and micro- tidal regions (Fig. 2B), while the lack of a gravel mode

327 resulted in significantly lower median bulk grain sizes when compared to MSG sites. The

328 shallowest beach face slopes in the study were observed at Nahant (Fig. 2C), which also was the

329 finest of all beaches sampled (Fig. 2B). At individual sites most beach face slope distributions

330 remained relatively similar seasonally, although regional medians revealed a slight drop in slope

331 during winter at mesotidal locations and a slight winter steepening at microtidal sites (Fig. 2C).

332 The most significant winter steepening was observed at the MSG beaches of Humarock, East and

333 Horseneck and finer grained Miacomet, while the most significant decreases in winter slopes

334 were at the finer grained beaches of Rockport and Low.

335

\section{$336 \quad 4.3$ Grain size relative to surficial geology}

337 Observed winter coarsening in regional medians of grain sizes indicate some oceanographic

338 control on beach characteristics (e.g. dashed orange and blue lines in Fig. 2A and 2B). However,

339 some of the finest-grained sandy beaches exhibited the greatest off-shore wave height, including

340 Low and Miacomet on Nantucket, while more sheltered nearby beaches of Sylvia and Town on

341 Martha's Vineyard were substantially coarser (Fig. 2A and 2B). Such inconsistencies indicate

342 that oceanographic effects are not the predominant control on grain size at the sites, supporting a 
343 basis for previous coastal classifications for this region that consider underlying geologic 344 conditions.

346 Grain sizes observed on the beaches in this study generally correspond to the relative grain sizes

347 observed within their respective source material (Fig. 3). For example, beaches associated with

348 fine stratified deposits were the finest grained, followed by coarse stratified deposits, and then

349 those sourced by a mixture of stratified deposits and till. Beaches sourced purely by till exhibited

350 the greatest range of grain sizes. Rockport and Nantasket appear to be anomalous. Though till

351 was available locally to these beaches, they are finer than expected when compared to other till-

352 sourced beaches in the study. With respect to sorting, grain size distributions obtained from

353 beaches either partially or fully sourced by till were poorly to very-poorly sorted (also with the

354 exception of Rockport). In contrast, a majority of beaches sourced by stratified drift are

355 moderately-to-well sorted (with the exception of Revere).

357 There is a marked distinction in grain size characteristics between beaches purely sourced by

358 stratified drift relative to ones sourced in part or fully by coarser and more poorly sorted till. As

359 noted, Rockport and Nantasket are presumably till-sourced but are anomalously fine-grained

360 beaches. We suspect the reworking of barrier/marsh material during transgression at Rockport

361 and the routine removal of gravel from Nantasket are responsible for them being anomalously

362 fine. Peggotty Beach is also somewhat finer grained relative to other mixed-source beaches in 363 the study. Due to public access restrictions, transects from Peggotty were limited to the finer

364 northern section of the beach, where overwash material is returned in spring following winter

365 storms. This sampling bias could therefore provide at least a partial explanation for the 


\section{EarthArXiv preprint under review in Marine Geology}

366 somewhat finer grains observed at the site and the lack of a predominant gravel mode evident

367 upon visual inspection to the south. Minus these discussed exceptions, however, sediment source

368 appears to exhibits a predominant control on grain size characteristics for beaches within the

369 study. In contrast, grain-size distinctions based on oceanographic conditions, when separated into

370 meso- and micro-tidal regions, or seasonal shifts in grain size due to summer-winter changes in

371 wave climatology are more subtle (Fig. 2).

372

373 Most grain size distributions for partially or fully till sourced beaches exhibit a bimodal

374 distribution of sand and gravel. The gravel mode for these systems result in overall coarser

375 sediments when using common metrics such as the median or bounds of the middle quantiles

376 (e.g. box plots in Fig. 3). However, when focused purely to the sand fraction, till sources systems

377 were generally finer than the unimodal pure-sand beaches sourced by coarse stratified deposits

378 (Fig. 3). Fine stratified deposits exhibited the finest sand fractions, followed by pure till sourced

379 systems, then those sourced by a mixture of till and stratified deposits, and finally systems

380 sourced purely from coarse stratified deposits.

381

382 Where gravel appears on the beach, we generally find it distributed throughout the exposed

383 cross-shore facies, consistent with the "mixed" class of sand and gravel beach of Jennings and

384 Schulmeister (2002). Synthesis of the bulk grain-size distribution of intertidal mixed sand and

385 gravel (at least 5\%>2 mm) samples are presented in Fig. $4(\mathrm{n}=454)$ and exhibit a distinct

386 bimodal distribution. This bimodality spans the entire study region and shows two separate peaks

387 between medium-to-very-coarse sand $(0.25 \mathrm{~mm}$ to $1 \mathrm{~mm})$ and medium-to-very-coarse gravel (10

$388 \mathrm{~mm}$ to $64 \mathrm{~mm})$. These peaks are separated by a local minimum centered at approximately 1 to 
$38910 \mathrm{~mm}$. However, the overall median of the distribution occurs at $2 \mathrm{~mm}$ (sand/gravel transition), 390 resulting from the coalescence of the separate sand and gravel modes. Independent analyses of

391 just bucket and bag samples $(\mathrm{n}=368)$, which were mechanically sieved also show similar

392 bimodality. Sand and gravel modes present in Fig. 4, as well as the paucity of grains between 1-

$39310 \mathrm{~mm}$, are therefore likely not an artifact of combining distributions from sieving and pebble

394 counts, but rather a persistent feature of sand and gravel beaches of southern New England.

\section{4.4. Beach face slope versus median grain size}

397 In Fig. 5 data is separated further into low, mid and high tide samples to assess intertidal trends 398 and generalizable consistencies. Comparison of median grain size and beach face slope data from 399 this study is generally consistent with the global data set compiled by Bujan et al. (2019).

400 Primary correspondence at all inter-tidal locations when compared to the broader Bujan et al.

401 (2019) global composite include: 1) an increase in beach face slope with grain size for $\mathrm{D}_{50}$ values 402 below $1 \mathrm{~mm}, 2$ ) an upper limit in beach face slope of roughly 0.2 , and 3) poor correlation 403 between grain size and slope for $\mathrm{D}_{50}$ values that exceed $\sim 1 \mathrm{~mm}$. In general, our data also exhibit 404 a plateau in slope beyond $1 \mathrm{~mm}$ that occurs within an approximate range of 0.1 and 0.2 .

405 However, a number of slope observations beyond a $\mathrm{D}_{50}$ of $1 \mathrm{~mm}$ exist well below this range in 406 slope, particularly at mid- and high- tide locations. Categorizing grain size measurements by 407 their degree of sorting reveals that samples with $\mathrm{D}_{50}$ values between $1-10 \mathrm{~mm}$ are all poorly 408 sorted, likely reflecting varying contribution of grains within abutting sandy and gravel modes 409 shown in Fig. 4. In contrast, moderately-to-well sorted samples all exhibit median grain sizes 410 that overlap well with the previously discussed sand $(0.25 \mathrm{~mm}$ to $1 \mathrm{~mm})$ or gravel (16 $\mathrm{mm}$ to 64 $411 \mathrm{~mm}$ ) modes, and with a skew towards better sorting at high-tide locations. 
413 Testing a common power-law fit to bulk $\mathrm{D}_{50}$ vs. beach face slope data results in a significant

414 under-prediction of slope when compared to previous data available from pure gravel beaches

415 (Fig. 6A). However, an improved fit with pure gravel systems was obtained when recomputing

416 the median grain size on just the sand component from our mixed sand and gravel beaches (i.e.,

417 removing the gravel component in the calculation, red plus signs in Fig. 6B).

\section{5. Discussion}

\section{5.1. Origins of beach bimodality}

420 Bimodality in grain-size distributions on southern New England beaches (Fig. 4), indicates two

421 separate and distinct sand and gravel populations which likely have very different and divergent

422 behaviors. Observed winter coarsening, particularly for MSG systems (Fig. 2), is primarily due

423 to the winnowing of sand during greater wave activity that is later returned during the summer

424 months. Anecdotal evidence for this phenomenon was observed first hand in the field with the

425 rapid erosion of sands by storms followed by rapid deposition during surveys at the beaches of

426 Barges, East and Humarock. In contrast, the separate gravel mode in Fig. 4 persists throughout

427 our seasonal surveys (Fig. 2B), and is restricted to locations nearest to its till-derived source (Fig.

428 3). This is particularly true for headland separated beaches where gravel exchange between

429 systems is unlikely (Fig. 1). Thus, our observations support gravel behaving more as a passive

430 lag deposit while sand represents the more active participant (e.g. Bluck, 1967), and as such,

431 exhibits the greater control on active beach slope (Fig. 6). However, beach bimodality is difficult

432 to explain solely by in situ processes since this high energy environment is continually reworked

433 by waves, which in turn provides a mechanism for sorting (Inman, 1949). A poorly sorted

434 bimodal sand and gravel beach therefore implies a sedimentary environment in disequilibrium, 


\section{EarthArXiv preprint under review in Marine Geology}

435 as is common for most environments where sediments are derived from post-glacial deposits 436 (e.g. Easterbrook, 1982).

438 Close relationships between glacial and post-glacial deposits and beach grain size described here 439 would suggest allochthonous sourcing of beach material, consistent with many models for sand 440 and gravel beaches generally. In Alaska (Hayes and Ruby, 1994), the British Isles (Carter and

441 Orford, 1984), Atlantic Canada (Orford et al., 2001), and New England (Fitzgerald and Van

442 Heteren, 1999), glacial till and post-glacial coarse stratified deposits intersect the coast.

443 Similarly, coastal reworking of adjacent ancient coarse-grained deposits mix with sand in

444 Taiwan (Hsieh et al., 2004), the northern Mediterranean (Ortega-Sánchez et al., 2017), and Baja

445 California (Emery, 1955). Alternatively, fluvial inputs combined with rapidly eroding

446 hinterlands, as in New Zealand (Bluck, 1967; Kirk, 1980) and the U.S. Pacific Coast (Bascom,

447 1951) can deliver both coarse and fine grained sediments directly to the beach.

449 McLean and Kirk (1969) provides one of the first accounts of beach bimodality based on surveys 450 along the northeast shoreline of the South Island of New Zealand. Building on Folk and Ward 451 (1957), sediment source was determined as the primary control on bimodal beach characteristics.

452 Oceanographic processes (e.g. waves and tides) were evaluated as secondary controls manifested 453 as variance around primary grain size trends. Later measurements by McLean (1970), however, 454 revealed unimodal sediments at size fractions between bimodal gravel and sand peaks. The in455 situ breakdown of parent greywacke rock derived from steep neighboring terrane was 456 hypothesized for grain sizes in all size fractions and it was concluded that sediment source might 457 not always be dominant in controlling beach grain size characteristics. Bimodal grain-size 


\section{EarthArXiv preprint under review in Marine Geology}

458 distributions have more recently been noted at other locations where MSG beaches are prevalent,

459 but with differences in the size of predominant modes and no unifying resultant grain size gap

460 (e.g. Bergillos et al., 2016; Horn and Walton, 2007; Pontee et al., 2004).

462 Bimodality in glacial deposits is well established (e.g. Easterbrook, 1982), where fine and coarse

463 grained modes in basal tills results from a combination of crushing (clast size) and abrasion

464 (matrix mode), (Dreimanis and Vagners, 1971). Transport breaks the rock down into two

465 components - one is clast size consisting of rock fragments, the second is till matrix consisting

466 of mineral fragments. Near the glacier source the clast size mode is always larger than matrix

467 mode but with increasing transport distance the matrix mode grows larger relative to the clast

468 mode (Dreimanis and Vagners, 1971). The gap between clast mode and matrix mode is thought

469 to be the dividing line between pure crushing by glacier movement and abrasion with the

470 threshold at $2 \mathrm{~mm}$ (Haldorsen, 2008). Bimodal distributions have been observed also in glacial

471 till lag deposits located offshore of the New England Coast (Pratt and Schlee, 1969).

472

473 Bimodality is also a characteristic of river deposits (e.g. Maizels, 1993; Rădoane et al., 2008;

474 Sambrook-Smith, 1996; Sambrook-Smith and Feruson, 1995) and by extension glacio-fluvial

475 systems. In narrower valleys bimodal distributions can be caused by overlapping two grain size

476 distributions of different origins. The coarse material is sourced by abrasion and hydraulic

477 sorting whereas the source of sand material may reach the river bed through hillslope erosion.

478 Rădoane et al. (2008) report two distinct peaks in Romania with minima in grain size between 1

479 and $8 \mathrm{~mm}$. In other instances, high flows move coarse material while lower flows bring in sand

480 which fills the interstices (Eynon and Walker, 1974). Mean velocities in excess of $300 \mathrm{~cm} / \mathrm{sec}$ 


\section{EarthArXiv preprint under review in Marine Geology}

481 will move the gravel as bed load while sand is transported in suspension. After the gravel is

482 deposited under lower flow conditions, the sand filters in creating strongly bimodal distributions

483 (Eynon and Walker, 1974).

484

485 Bimodality in rivers are also commonly discussed in the form of abrupt gravel to sand transitions

486 (e.g. Ferguson et al., 1996; Parker and Cui, 1998; Sambrook-Smith and Feruson, 1995; Shaw and

487 Kellerhals, 1982). These gravel to sand transitions (GST) often migrate over time (Ferguson,

488 2003; Marr et al., 2000; Robinson and Slingerland, 1998), resulting in a depositional sequence

489 that is as a whole distinctly bimodal (Marr et al., 2000; Paola et al., 1992). No universal theory

490 currently exists to explain GST (Dingle et al., 2020), although the phenomena is well

491 documented as well as a resultant 1-10 mm gap in grain size similar to that observed in Fig. 4

492 (e.g. Dade and Friend, 1998; Wolcott, 1988). Possible explanations for this grain size gap

493 include grain-size dependent changes in particle breakdown or comminution (Jerolmack and

494 Brzinski, 2010), nonlinearities in bedload transport (Ferguson, 2003), transitions from viscous-

495 to-turbulent dependent sediment suspension thresholds (Lamb and Venditti, 2016), a switch from

496 washload to suspended/bedload transport of sands (Dingle et al., 2020), and shifts from gravel

497 beds to cohesive channel banks as the predominant control on channel geometries for gravel and

498 sandy channels (Dunne and Jerolmack, 2018).

499

500 Current theory predominantly prescribes fluvial bimodality to along channel changes in river

501 transport and is less relevant to wave-induced transport in beach settings. This is with the

502 exception potentially of the ablation mechanisms put forth by Jerolmack and Brzinski (2010).

503 However, unimodal beaches with distributions between 1-10 $\mathrm{mm}$ have been observed previously 
504 (e.g. McLean, 1970) and suggest that the bimodality observed in our New England beach

505 systems are not globally generalizable, but rather a characteristic common to systems sourced

506 predominantly from glacial and fluvial deposits where the presence of a 1-10 mm grain size gap

507 is well established. Thus, we interpret the bimodality in our paraglacial beach systems to be

508 largely inherited from the glacial and fluvial deposits upon which they are derived, yet with

509 resulting behaviors including grain size vs. slope relationship that are unique (e.g. Fig. 6),

510 relative to the unimodal sandy systems described in detail by Bascom er al. (1951).

\subsection{Processes governing beach face slope on mixed bimodal beaches}

513 Many have noted previously the likely impacts of bimodality on relating grain size to beach face

514 slope (e.g. Zenkovich, 1967), first with respect to the ineffectiveness of a single metric such as

515 median or mean grain size in describing bimodal grain size distributions (Sambrook-Smith et al.,

516 1997), and second for the predominant roll of the sand fraction in determining beach

517 permeability and in turn sediment transport and morphology (e.g Holmes et al., 1996; Mason et

518 al., 1997; Mason and Coates, 2001; Quick and Dyksterhuis, 1994).

519

520 Bascom (1951) invites the use of median grain size $\left(D_{50}\right)$ to describe beach facies because

521 excellent sorting generally allows this single metric to adequately capture these environments.

522 However, where sediment is not well sorted, and particularly for bimodal beaches, there is no

523 reason to expect median or mean grain size to correspond to beach face slope. Many of the

524 beaches described here include gravel (and cobble), yet follow the slope predicted by their sand

525 components (Fig. 6B), while bulk median grain size cannot predict slope for these coarser

526 bimodal systems (Fig. 6A). 
528 All the beaches in the Massachusetts study include a substantial sand component ( $>25 \%$ for bulk 529 seasonal distributions, Fig 2B), and given sand's leading role in both transport and permeability,

530 it appears likely that the characteristic of this sand component provides a predominant control on

531 beach slope (Fig. 6B). As at other sand and gravel beaches (Jennings and Shulmeister, 2002),

532 there appears to be a high threshold (Masselink and Li, 2001) for coarse material content before

533 beach face slope again begins to correspond to the bulk median grain size (Bujan et al., 2019).

535 Our work highlights the need for additional research on the predominant processes and potential

536 governors of beach face slope for bimodal beaches common to the glaciated New England

537 region. Past works provide support for two key aspects of sand preferentially controlling beach

538 morphology in bimodal systems. First, fine grains are transported more easily, can be suspended

539 more easily, and fall more slowly, thus potentially playing a more dynamic role in determining

540 the morphology of bimodal mixed sand and gravel systems. Second, and likely more

541 importantly, finer sands restrict the hydraulic conductivity of the beach, and, in turn, the degree

542 of swash infiltration and effluent during rising and falling tides, respectively. Hydraulic

543 conductivity increases with grain size diameter in a non-linear fashion: slowly in sand, then

544 increasingly rapidly in gravel (Buscombe and Masselink, 2006; Horn, 2002; Krumbein and

545 Monk, 1943). On timescales of tidal fluctuations, high porosity of gravel $\left(\mathrm{D}_{50}>3 \mathrm{~mm}\right)$ allows

546 good circulation; intermediate porosity of coarse sand ( $\left.3 \mathrm{~mm}>\mathrm{D}_{50}>0.5 \mathrm{~mm}\right)$ allows poor

547 circulation; low porosity of medium and fine sand $\left(\mathrm{D}_{50}<0.5 \mathrm{~mm}\right)$ allows virtually none

548 (Bagnold, 1940). The amplitude and phasing of water table fluctuations at the beach face with

549 respect to the tide are determined by the porosity, and thus the grain size of beach material 


\section{EarthArXiv preprint under review in Marine Geology}

550 should determine whether infiltration into and effusion from material shape the beach face

551 (Masselink and Li, 2001).

552 As mentioned, finer sands not only restrict groundwater flow, but smaller grains are carried more

553 easily due to their lower fall velocities, and the slope of the beach face moderates the speed of

554 the uprush and backwash, further sorting sand. The uprush moves sand landward more

555 effectively than the backwash because of its faster speed, shorter duration, and enhanced

556 suspension of sediments in the boring action of breaking waves (Masselink and Hughes, 1998).

557 Swash infiltration becomes an increasingly trivial process for medium and fine sand $(<0.5 \mathrm{~mm})$

558 (Bagnold, 1940), so fall velocity becomes the dominant factor controlling slope for finer sand

559 beach faces (Dubois, 1972). Too coarse and the sand becomes stranded on the berm in the

560 uprush; too fine and the sand is carried deeper offshore (Bascom, 1951). Thus, waves and tides

561 sort sand effectively in the intertidal zone, with slope corresponding to the appropriate grain size

562 (Bascom, 1951).

563 Following this explanation for beach slope, the plateau in slope near the sand-gravel transition

564 noted by Bujan et al. (2019) could in part be caused by mixed sand and gravel systems where

565 reduced slopes are limited by their sand component. Comparison to the mixed sand and gravel

566 versus pure gravel beaches of Jennings and Schulmeister (2002) included in the Bujan et al.

567 (2019) metanalysis illustrates this aspect of the aggregate data set. Specifically, the lower

568 porosities and fall velocities of the substantial sand components on these beaches shape the

569 shoreface resulting in shallower slopes, as observed in many of the Massachusetts beaches

570 studied here. Considering coarser beaches generally, however, with increasing median grain size

571 (cobble), we suspect that a diminishing sand component becomes increasingly excluded from

572 these higher energy systems, explaining why slopes of cobbly beach faces composed 
573 predominantly of pure-gravel more reliably steepen beyond mixed sand and gravel systems with

574 median grain size in the gravel range (e.g. Fig. 6B; Jennings and Schulmeister, 2002).

575

\section{$576 \quad 5.3$ Oceanographic Impacts}

577 Oceanographic factors may provide additional secondary explanations for the scatter observed

578 between grain size and slope along the Massachusetts beaches, particularly when gravel is

579 removed and comparisons are made between median sand size and beach face slope. Increasing

580 tidal range typically corresponds to an increase in beach width (Masselink and Short, 1993), and

581 could in part explain the shallower slopes for the meso-tidal beaches relative to their micro-tidal

582 counterparts (Fig. 2C). However, the same general sand $\mathrm{D}_{50}$ vs. slope relationships hold even

583 when observations are categorized into their predominant oceanographic setting (Fig. 7). This is

584 true both in terms of micro- vs. meso-tidal ranges (Fig. 7, top right panel) and summer-winter

585 wave climatology (Fig. 7, bottom right). If true, the general decrease in bulk grain size observed

586 for our meso-tidal relative to micro-tidal systems would provide support for feedbacks, where

587 beach slope is adjusted in part via a reduction in grain size for these systems.

588

589 We suspect tidal regime to be the predominant control on regional differences in slope north and 590 south of Cape Cod. However, an alternative explanation for greater slopes for beaches south of

591 Cape Cod is that there is a paucity of finer-grained beaches in this region as a result of its unique

592 depositional setting. Whereas in the north fine-grained glaciomarine deposits are widespread

593 across Massachusetts Bay and Cape Cod Bay, many of the beaches south of Cape Cod are

594 proximal to the late Wisconsinan terminal moraine or the Buzzards Bay recessional moraine.

595 Accordingly, this close proximity to the ice margin may have resulted in higher depositional 


\section{EarthArXiv preprint under review in Marine Geology}

596 energy producing a general coarsening of sand within associated stratified deposits. The southern

597 mixed till/stratified source beaches of Sylvia, Town and Surf show some evidence of courser

598 sands when compared to the northern beaches of Peggotty, Humarock and Marshfield (Fig. 3).

599 However north-south differences for other sediment sourcing categories in Fig. 3 are less

600 conclusive.

601

602 With respect to oceanographic conditions, waves provide another potential control on beach

603 characteristics in addition to tides (e.g. Masselink and Short, 1993). Primary evidence for waves

604 controlling grain size at our sites include a general coarsening in median grain size for the winter

605 surveys relative to summer (blue vs. orange dashed lines in Fig. 2B). When categorized by

606 season, winter beach face slopes appears to plot slightly lower than its summer counterpart at the

607 northern meso-tidal locations (Fig. 2C), consistent with flattening of the beach during landward

608 translation of the face during winter. Although we observed clear landward retreat of some of the

609 sandier beaches (Salisbury, Peggotty, Rockport, Low) during winter, on coarser beaches

610 advance/retreat results are mixed from one transect to the next and the beach appeared to move

611 little in aggregate seasonally. We therefore interpret the general summer-to-winter bulk

612 coarsening in Fig. 2 as representing a partial removal of some of the sand fraction in the surface

613 layer of these beaches. An increase in winter wave activity therefore appears sufficient enough to

614 winnow sands and coarsen the resultant median grain size (Fig. 2B), but the amounts removed

615 are insufficient to cause a significant, generalizable seasonal change in beach face slope (Fig.

$6162 \mathrm{C})$.

617

618 


\subsection{Future Work}

620 Considering sand versus MSG beaches, we return to Bascom's five tenets with greater

621 appreciation for how coarse material interrupts patterns predicted for otherwise sandy systems.

622 Regarding 1) that the intertidal zones of fine sandy beaches are flatter than those of coarse sandy

623 beaches, we find that this holds true for the sand fraction. Future work might build on how sand

624 continues to control beach slope when gravel is included. Regarding 2) that beach material at any

625 place is well sorted, we find this true for the sand fraction, though not true for bulk material.

626 Previous studies recognize both mixed (e.g. this study) and composite classes of sand and gravel

627 beaches, where good sorting at any point is followed. Why one form or the other appears along

628 the coast is an open question in beach research. To 3) that sorting occurs by facies, with plunge

629 point (where wave uprush and backwash intersect) being coarsest, then summer berm, the

630 intertidal zone, dune sand, and the finest material with increasing depth under water, we find a

631 slightly different pattern with the coarsest material found stranded within high-tide facies.

632 Instead of clear evidence for 4) that beaches build seaward and steepen under gently sloping

633 waves and are cut back and flattened by steep waves, we find that high-energy waves winnow

634 sand to leave a coarser winter beach face, whereas sand becomes reincorporated under low

635 energy summer waves. MSG beaches use a step to accommodate wave energy (e.g. Masselink et

636 al., 2010), which may explain insensitivity in breach face slope and facies positions to changing

637 wave climate observed here. Finally, we cannot resolve 5) that wave exposure sorts material into

638 appropriate environments along the coast. Along the complex postglacial coast the general

639 distribution of the sand component's distribution on the beach is poorly understood. Further

640 research is needed to evaluate how availability of nearby sand deposits determines fine beach 


\section{EarthArXiv preprint under review in Marine Geology}

641 material versus in situ sorting of this sand fraction into appropriate coastal environments by 642 oceanographic processes.

\section{6. Conclusions}

645 Post-glaciated beaches in the New England region are relatively unique to the U.S., yet represent

646 important examples of the global subset of beaches composed of both sand and gravel. Glacial

647 till and outwash/fluvial deposits are the primary sources of gravel and sand to local beaches in

648 the region, respectively, and the relative contribution of these two sources serve as the

649 predominant control on aggregate beach grain size. Oceanographic factors exhibit secondary

650 controls with an increase in beach slope for micro- versus meso-tidal systems, and a general

651 summer-to-winter coarsening due to the seasonal winnowing of sands. Combining all beach

652 grain size distributions from the region reveals two separate modes of medium-to-very-coarse

653 sand and medium-to-very-coarse gravel separated by a lack of grains between 1 and $10 \mathrm{~mm}$. This

654 gap in grain size is common to paraglacial and fluvial deposits upon which sediment to regional

655 beaches in New England are derived and suggests an allochthonous rather than autochthonous

656 cause. Median grain size or $\mathrm{D}_{50}$ is a common metric used for predicting active beach slope for

657 unimodal beaches, but our work supports past observations on $\mathrm{D}_{50}$ being less effective when

658 applied to bimodal mixed sand and gravel beaches. Similar to these past studies we observe

659 beach slope predictably increases with grain size up to a bulk $\mathrm{D}_{50}$ of $\sim 1 \mathrm{~mm}$, and a lack of

660 correspondence beyond this median size. For coarser mixed sand and gravel systems the $\mathrm{D}_{50}$ of

661 the sand fraction better predicts beach face slope, and follows a similar $\mathrm{D}_{50}$ vs. slope relationship

662 as that observed using bulk $\mathrm{D}_{50}$ for finer, sandy unimodal beaches. Comparisons to pure gravel

663 beaches reveals that a relatively high fractional content of gravel is likely required in order for 
664 beach face slope to correspond to bulk median grain size. Grain size distributions of sand serve 665 as the primary governor of beach face permeability and sediment transport in bimodal systems,

666 which together likely explain why it has greater observed control on beach morphology for 667 mixed sand and gravel systems.

669 Acknowledgements

670 University of Massachusetts undergraduates J. Light, M. Cashman, S. Gessay, S. Osgood, N.

671 Doiron, A. Chica, J. Healey, J. Jurnack, M. Koerth, and P. Southard assisted in the field and lab

672 work. M. Mansfield, R. Haney, J. Burtner, K. Glenn, and J. Knisel from MA Coastal Zone

673 Management gave guidance and logistical support throughout the project. M. Borrelli from

674 UMass-Boston and Center for Coastal Studies and R. Newton of Smith College contributed 675 technical assistance and positioning equipment for beach surveys, and J. Warner assisted with 676 access to COAWST model results. Woodruff is grateful for support by the University of Maine 677 Darling Marine Center which provided residency during the completion of this manuscript. This 678 research was funded by the U.S. Department of Interior, Bureau of Ocean Energy Management 679 under cooperative agreement M14AC00006. The views and conclusions contained in this 680 document are those of the authors and should not be interpreted as representing the opinions or 681 policies of the U.S. Government. Mention of trade names or commercial products does not 682 constitute their endorsement by the U.S. Government. 


\section{EarthArXiv preprint under review in Marine Geology}

686 Figure 1. Regional Massachusetts coastline (upper left panel) and study area locations shown in 687 panels A-F, along with transect locations (black circles), surficial geology with key provided.

688 Text boxes indicate location of each beach in study as well as its predominant surficial geology

689 (modified from Stone and others, 2018).

690

691 Figure 2: (A) Significant wave height $-\mathrm{H}_{\text {sig, }}$, and (B) combined grain size and (C) beach face 692 slope distributions for summer (orange) and winter (blue) surveys. Beach sites arranged north-to693 south (left-to-right). $\mathrm{H}_{\text {sig }}$ averages (bars) and 12-hr averaged maxima (circles) are over the 30694 days prior to surveying. Box plots in B and C include the median (thick horizonal line), bounds 695 average 12-hr maxima and median grain size and slope for meso- and micro- tidal regions shown 696 as dashed horizonal orange and blue lines, respectfully.

697

698 Figure 3: Bulk grain size distribution for sites and arranged with respect to their predominant 699 sediment source. Box plots include the median (thick horizonal line), bounds of middle quantiles 700 (boxes) and $10^{\text {th }}$-to- $90^{\text {th }}$ percentiles (thin vertical line).

701

702 Figure 4: Composite grain size distribution of binned (blue) and cumulative (red) percent for all 703 intertidal mixed sand and gravel samples (MSG). Here MSG samples are defined as greater than $7045 \%$ of distribution exceeding $2 \mathrm{~mm}(\mathrm{n}=454)$.

705

706 Figure 5: Median $\left(\mathrm{D}_{50}\right)$ grain size versus beach face slope for low tide (left panel), mid tide

707 (middle panel) and high tide (right panel) compared to the global data set of Bujan et al. (2019).

708 Moderately-to-well sorted samples (circles) and poorly sorted samples (plus markers) are defined 
709 by criteria presented by Blott and Pye (2001). The same global data set from Bujan et al. (2019)

710 is shown in each panel (gray asterisk) where grain sizes represents either a $\mathrm{D}_{50}$ or mean and were

711 obtained by a variety of methods provided by references therein.

712

713 Figure 6: (A) Median grain size versus beach face slope for MSG (plus signs) and pure sand 714 beaches (black circles) in this study compared to data by Jennings and Schulmeister (2002) for 715 pure gravel beaches (J\&S,2002, black triangles). Left panel is bulk $\mathrm{D}_{50}$ grain size and right panel 716 is the median grain size of just the isolated sand fraction (i.e. median for distribution $<2 \mathrm{~mm}$ ).

717 Power law fits (dashed lines) are provided for bulk $\mathrm{D}_{50}$ and median size in sand fraction ( $\left.\mathrm{Ds}_{50}\right)$

718 versus beach face slope (S). Values of best fit for right panel in the form of $S=a^{*} \operatorname{Ds}_{50} \wedge b+c$ and

719 fitted parameters of $\mathrm{a}=-0.10, \mathrm{~b}=-0.37$, and $\mathrm{c}=0.22$.

720

721 Figure 7: Beach face slope versus bulk median grain size (left panels) and median grain size for 722 sand fraction (right panels) categorized by tidal region (top panels) and season (bottom panels). 723 


\section{References}

726

727 Bagnold, R.A., 1940. Beach formation by waves: some model experiments in a wave tank.

728 Journal of the Institution of Civil Engineers 15, 27-52.

729 Barnhardt, W.A., Ackerman, S.D., Andrews, B.D., Baldwin, W.E., 2010. Geophysical and 730 sampling data from the inner continental shelf: Duxbury to Hull, Massachusetts. US 731 Geological Survey.

732 Barnhardt, W.A., Andrews, B.D., Ackerman, S.D., Baldwin, W.E., Hein, C.J., 2009. High733 Resolution Geologic Mapping of the Inner Continental Shelf: Cape Ann to Salisbury 734 Beach, Massachusetts. US Geological Survey.

735 Bascom, W.N., 1951. The relationship between sand size and beach-face slope. Eos, 736 Transactions American Geophysical Union 32, 866-874. https://doi.org/10.1029/TR032i006p00866

738 Bergillos, R.J., Ortega-Sánchez, M., Masselink, G., Losada, M.A., 2016. Morpho-sedimentary dynamics of a micro-tidal mixed sand and gravel beach, Playa Granada, southern Spain.

741 Billy, J., Robin, N., Hein, C.J., Certain, R., FitzGerald, D.M., 2015. Insight into the late

742 Holocene sea-level changes in the NW Atlantic from a paraglacial beach-ridge plain 743 south of Newfoundland. Geomorphology 248, 134-146.

744 https://doi.org/10.1016/j.geomorph.2015.07.033

745 Blott, S.J., Pye, K., 2001. GRADISTAT: a grain size distribution and statistics package for the 746 analysis of unconsolidated sediments. Earth Surface Processes and Landforms 26, 1237747 1248. https://doi.org/10.1002/esp.261 


\section{EarthArXiv preprint under review in Marine Geology}

748 Bluck, B.J., 1967. Sedimentation of beach gravels; examples from South Wales. Journal of 749 Sedimentary Research 37, 128-156.

750 Bujan, N., Cox, R., Masselink, G., 2019. From fine sand to boulders: Examining the relationship 751 between beach-face slope and sediment size. Marine Geology 417, 106012.

$752 \quad$ https://doi.org/10.1016/j.margeo.2019.106012

753 Buscombe, D., Masselink, G., 2006. Concepts in gravel beach dynamics. Earth-Science Reviews 754 79, 33-52. https://doi.org/10.1016/j.earscirev.2006.06.003

755 Caldwell, N.E., Williams, A.T., 1985. The Role of Beach Profile Configuration in the 756 Discrimination between Differing Depositional Environments Affecting Coarse Clastic 757 Beaches. Journal of Coastal Research 1, 129-139.

758 Carter, R.W.G., Forbes, D.L., Jennings, S.C., Orford, J.D., Shaw, J., Taylor, R.B., 1989. Barrier 759 and lagoon coast evolution under differing relative sea-level regimes: examples from 760 Ireland and Nova Scotia. Marine Geology 88, 221-242. https://doi.org/10.1016/0025$761 \quad 3227(89) 90099-6$

762 Carter, R.W.G., Johnston, T.W., McKenna, J., Orford, J.D., 1987. Sea-level, sediment supply 763 and coastal changes: examples from the coast of Ireland. Progress in Oceanography 18, $764 \quad 79-101$.

765 Carter, R.W.G., Orford, J.D., 1993. The Morphodynamics of Coarse Clastic Beaches and 766 Barriers: A Short- and Long-term Perspective. Journal of Coastal Research 158-179.

767 Carter, R.W.G., Orford, J.D., 1984. Coarse clastic barrier beaches: a discussion of the distinctive 768 dynamic and morphosedimentary characteristics, in: Developments in Sedimentology. $769 \quad$ Elsevier, pp. 377-389. 


\section{EarthArXiv preprint under review in Marine Geology}

770 Dade, W.B., Friend, P.F., 1998. Grain-Size, Sediment-Transport Regime, and Channel Slope in

771 Alluvial Rivers. The Journal of Geology 106, 661-676. https://doi.org/10.1086/516052

772 Dingle, E.H., Sinclair, H.D., Venditti, J.G., Attal, M., Kinnaird, T.C., Creed, M., Quick, L.,

773 Nittrouer, J.A., Gautam, D., 2020. Sediment dynamics across gravel-sand transitions:

774 Implications for river stability and floodplain recycling. Geology 48, 468-472.

775 https://doi.org/10.1130/G46909.1

776 DiPietro, J.A., 2012. Landscape evolution in the United States: an introduction to the geography, 777 geology, and natural history. Elsevier.

778 DiTroia, A., 2019. Legacy Sediment Controls on Post-Glacial Beaches of Massachusetts

779 (Masters Theses). University of Massachusetts, Amherst, MA USA.

780 Dreimanis, A., Vagners, U.J., 1971. Bimodal distribution of rock and mineral fragments in basal 781 tills, in: Goldthwait, R.P. (Ed.), Till, a Symposium. Ohio State University Press, 782 Columbus, Ohio, pp. 237-250.

783 Dubois, R.N., 1972. Inverse relation between foreshore slope and mean grain size as a function of the heavy mineral content. Geological Society of America Bulletin 83, 871-876.

785 Dunne, K.B.J., Jerolmack, D.J., 2018. Evidence of, and a proposed explanation for, bimodal transport states in alluvial rivers. Earth Surf. Dynam. 6, 583-594. https://doi.org/10.5194/esurf-6-583-2018

788 Easterbrook, D.J., 1982. Characteristic features of glacial sediments, in: Sandstone Depositional 789 Environments. American Association of Petroleum Geologists.

790 Emery, K.O., 1955. Grain Size of Marine Beach Gravels. The Journal of Geology 63, 39-49. 
791 Emery, K.O., Wigley, R.L., Bartlett, A.S., Rubin, M., Barghoorn, E.S., 1967. Freshwater peat on 792 the continental shelf. Science 158, 1301-1307.

793 https://doi.org/10.1126/science.158.3806.1301

794 Engelhart, S.E., Horton, B.P., 2012. Holocene sea level database for the Atlantic coast of the $795 \quad$ United States. Quaternary Science Reviews 54, 12-25.

796 Eynon, G., Walker, R.G., 1974. Facies relationships in Pleistocene outwash gravels, southern 797 Ontario: a model for bar growth in braided rivers. Sedimentology 21, 43-70.

798 Fenneman, N.M., 1938. Physiography of Eastern United States.

799 Fenneman, N.M., 1917. Physiographic divisions of the United States. Proc. Natl. Acad. Sci. 3, $800 \quad 17-22$.

801 Fenneman, N.M., 1916. Physiographic divisions of the United States. Ann. Assoc. Amer. Geog. $802 \quad 6,19-98$.

803 Ferguson, R., Hoey, T., Wathen, S., Werritty, A., 1996. Field evidence for rapid downstream 804 fining of river gravels through selective transport. Geology 24, 179-182.

805 Ferguson, R.I., 2003. Emergence of abrupt gravel to sand transitions along rivers through sorting $806 \quad$ processes. Geology 31, 159-162.

807 Finch, J., 1823. Geological Essay on the Tertiary Formations in America...

808 FitzGerald, D.M., Rosen, P.S., 1988. USA--Massachusetts, in: Walker, H.J. (Ed.), Artificial 809 Structures and Shorelines, The GeoJournal Library. Springer, pp. 545-560.

810 Fitzgerald, D.M., Van Heteren, S., 1999. Classification of paraglacial barrier systems: coastal 811 New England, USA. Sedimentology 46, 1083-1108. https://doi.org/10.1046/j.13653091.1999.00266.x 


\section{EarthArXiv preprint under review in Marine Geology}

813 Folk, R.L., Ward, W.C., 1957. Brazos River Bar: A Study in the Significance of Grain Size Parameters. Journal of Sedimentary Petrology 27, 3-26.

815 Forbes, D.L., Orford, J.D., Carter, R.W.G., Shaw, J., Jennings, S.C., 1995. Morphodynamic 816 evolution, self-organisation, and instability of coarse-clastic barriers on paraglacial coasts. Marine Geology 126, 63-85. https://doi.org/10.1016/0025-3227(95)00066-8

818 Forbes, D.L., Syvitski, J.P., 1994. Paraglacial coasts. Coastal Evolution: Late Quaternary Shoreline Morphodynamics. Cambridge University Press, Cambridge 373-424.

820

821

822

823

824

825

826

827

828

829

830

831

832

833

834 835
Haldorsen, S., 2008. Grain-size distribution of subglacial till and its realtion to glacial scrushing and abrasion. Boreas 10, 91-105. https://doi.org/10.1111/j.1502-3885.1981.tb00472.x

Hayes, M.O., 1979. Barrier island morphology as a function of tidal and wave regime. In: Leatherman SP (ed) Barrier Islands. Academic Press, New York 1, 27.

Hayes, M.O., Ruby, C.H., 1994. Barriers of Pacific Alaska, in: Geology of Holocene Barrier Island Systems. Springer, Berlin, Heidelberg, pp. 395-433.

Hein, C.J., Fallon, A.R., Rosen, P., Hoagland, P., Georgiou, I.Y., FitzGerald, D.M., Morris, M., Baker, S., Marino, G.B., Fitzsimons, G., 2019. Shoreline Dynamics Along a Developed River Mouth Barrier Island: Multi-Decadal Cycles of Erosion and Event-Driven Mitigation. Front. Earth Sci. 7, 103. https://doi.org/10.3389/feart.2019.00103

Hein, C.J., FitzGerald, D.M., Buynevich, I.V., Van Heteren, S., Kelley, J.T., 2014. Evolution of paraglacial coasts in response to changes in fluvial sediment supply. Geological Society, London, Special Publications 388, 247-280.

Holmes, P., Baldock, T.E., Chan, R.T., Neshaei, M.A.L., 1996. Beach evolution under random waves. Presented at the 25th International Conference on Coastal Engineering, pp. 30063019. 
836 Horn, D.P., 2002. Beach groundwater dynamics. Geomorphology 48, 121-146. https://doi.org/10.1016/S0169-555X(02)00178-2

838

839

840

841

842

843

844

845

846

847

848

849

850

851

852

853

854

855 Jerolmack, D.J., Brzinski, T.A., 2010. Equivalence of abrupt grain-size transitions in alluvial

856

857

Horn, D.P., Walton, S.M., 2007. Spatial and temporal variations of sediment size on a mixed sand and gravel beach. Sedimentary Geology 202, 509-528. https://doi.org/10.1016/j.sedgeo.2007.03.023

Hsieh, M.-L., Liew, P.-M., Hsu, M.-Y., 2004. Holocene tectonic uplift on the Hua-tung coast, eastern Taiwan. Quaternary International 115-116, 47-70. https://doi.org/10.1016/S1040-6182(03)00096-X

Inman, D.L., 1949. Sorting of sediments in the light of fluid mechanics. Journal of Sedimentary Research 19, 51-70.

Irish, J.D., Signell, R.P., 1992. Tides of Massachusetts and Cape Cod Bays. Woods Hole Oceanographic Institution.

Ivamy, M.C., Kench, P.S., 2006. Hydrodynamics and morphological adjustment of a mixed sand and gravel beach, Torere, Bay of Plenty, New Zealand. Marine Geology 228, 137-152. https://doi.org/10.1016/j.margeo.2006.01.002

Jennings, R., Shulmeister, J., 2002. A field based classification scheme for gravel beaches. Marine Geology 186, 211-228.

Jennings, S., Smyth, C., 1990. Holocene evolution of the gravel coastline of East Sussex. Proceedings of the Geologists' Association 101, 213-224. rivers and eolian sand seas: A hypothesis. Geology 38, 719-722. https://doi.org/10.1130/G30922.1 
858 Kelley, J.T., 1987. An Inventory of Coastal Environments and Classification of Maine's

859 Glaciated Shoreline, in: FitzGerald, D.M., Rosen, P.S. (Eds.), Glaciated Coasts.

860 Academic Press, Inc, San Diego, pp. 151-176.

861 Kirk, R.M., 1980. Mixed sand and gravel beaches: morphology, processes and sediments.

862 Progress in Physical Geography 4, 189-210.

863 Koteff, C., Pessl, F., 1981. Systematic ice retreat in New England (U.S. Geological Survey 864 Professional Paper No. 1179).

865 Krumbein, W.C., Monk, G.D., 1943. Permeability as a function of the size parameters of

866 unconsolidated sand. Transactions of the AIME 151, 153-163.

867 Lamb, M.P., Venditti, J.G., 2016. The grain size gap and abrupt gravel-sand transitions in rivers

868 due to suspension fallout. Geophysical Research Letters 43, 3777-3785.

$869 \quad$ https://doi.org/10.1002/2016GL068713

870 Luijendijk, A., Hagenaars, G., Ranasinghe, R., Baart, F., Donchyts, G., Aarninkhof, S., 2018.

871 The State of the World's Beaches. Sci Rep 8, 6641. https://doi.org/10.1038/s41598-018-

$872 \quad 24630-6$

873 Maizels, J., 1993. Lithofacies variations within sandur deposits: the role of runoff regime, flow

874 dynamics and sediment supply characteristics. Sedimentary Geology 85, 299-325.

$875 \quad$ https://doi.org/10.1016/0037-0738(93)90090-R

876 Marr, J.G., Swenson, J.B., Paola, C., Voller, V.R., 2000. A two-diffusion model of fluvial

877 stratigraphy in closed depositional basins. Basin Research 12, 381-398.

878 https://doi.org/10.1111/j.1365-2117.2000.00134.x 


\section{EarthArXiv preprint under review in Marine Geology}

879 Martínez, M.L., Intralawan, A., Vázquez, G., Pérez-Maqueo, O., Sutton, P., Landgrave, R., 2007. The coasts of our world: Ecological, economic and social importance. Ecological Economics 63, 254-272. https://doi.org/10.1016/j.ecolecon.2006.10.022

882

Mason, T., Coates, T.T., 2001. Sediment Transport Processes on Mixed Beaches: A Review for Shoreline Management. Journal of Coastal Research 17, 645-657.

Mason, T., Voulgaris, G., Simmonds, D.J., Collins, M.B., 1997. Hydrodynamics and sediment transport on composite (mixed sand/shingle) and sand beaches: A comparison, in: Thornton, E.B. (Ed.), Coastal Dynamics. American Society of Civil Engineers, New York, pp. 48-57.

Masselink, G., Hughes, M., 1998. Field investigation of sediment transport in the swash zone. Continental Shelf Research 18, 1179-1199. https://doi.org/10.1016/S02784343(98)00027-2

Masselink, G., Li, L., 2001. The role of swash infiltration in determining the beachface gradient: a numerical study. Marine Geology 176, 139-156.

Masselink, G., Russell, P., Blenkinsopp, C., Turner, I., 2010. Swash zone sediment transport, step dynamics and morphological response on a gravel beach. Marine Geology 274, 5068. https://doi.org/10.1016/j.margeo.2010.03.005

Masselink, G., Short, A.D., 1993. The Effect of Tide Range on Beach Morphodynamics and Morphology: A Conceptual Beach Model. Journal of Coastal Research 9, 785-800.

Masterson, J.P., Stone, B.D., Walter, D.A., Savoie, J.G., 1997. Hydrogeologic framework of western Cape Cod, Massachusetts (U.S. Geological Survey Hydrologic Investigations Atlas No. 741). 
901 Mather, K.F., Goldthwait, R.P., Thiesmeyer, L.R., 1942. Pleistocene geology of western Cape

902 Cod, Massachusetts. Bulletin of the Geological Society of America 53, 1127-1174.

903 McLean, R.F., 1970. Variations in grain-size and sorting on two kaikoura beaches. New Zealand

$904 \quad$ Journal of Marine and Freshwater Research 4, 141-164.

905 https://doi.org/10.1080/00288330.1970.9515334

906 McLean, R.F., Kirk, R.M., 1969. Relationships between grain size, size-sorting, and foreshore 907 slope on mixed sand - shingle beaches. New Zealand Journal of Geology and Geophysics 12, 138-155. https://doi.org/10.1080/00288306.1969.10420231

Ockay, C., Hubert, J.F., 1996. Mineralogy and provenance of Pleistocene outwash-plain and modern beach sands of outer Cape Cod, Massachusetts, USA. Marine Geology 130, 121137. https://doi.org/10.1016/0025-3227(95)00125-5

912 Oldale, R.N., Barlow, R.A., 1986. Geologic map of Cape Cod and the islands, Massachusetts (Miscellaneous Investigations Series Map No. I-1763). United States Geological Survey.

914 Oldale, R.N., Colman, S.M., Jones, G.A., 1993. Radiocarbon ages from two submerged strandline features in the western Gulf of Maine and a sea-level curve for the northeastern Massachusetts coastal region. Quaternary Research 40, 38-45.

920 Orford, J.D., Jennings, S.C., Forbes, D.L., 2001. Origin, development, reworking and breakdown of gravel-dominated coastal barriers in Atlantic Canada: future scenarios for the British coast, in: Packham, J.R., Barnes, R.S.K., Neals, A. (Eds.), Ecology \& Geomorphology of Coastal Shingle. Westbury, pp. 23-55. 
924 Ortega-Sánchez, M., Bergillos, R.J., López-Ruiz, A., Losada, M.A., 2017. Morphodynamics of 925 mediterranean mixed sand and gravel coasts. Springer.

926 Paola, C., Heller, P.L., Angevine, C.L., 1992. The large-scale dynamics of grain-size variation in 927 alluvial basins, 1: Theory. Basin research 4, 73-90.

928 Parker, G., Cui, Y., 1998. The arrested gravel front: stable gravel-sand transitions in rivers Part 929 1: Simplified analytical solution. Journal of hydraulic research $36,75-100$.

930 Peltier, W.R., 2004. Global glacial isostasy and the surface of the ice-age Earth: the ICE-5G 931 (VM2) model and GRACE. Annu. Rev. Earth Planet. Sci. 32, 111-149.

932 Pontee, N.I., Pye, K., Blott, S.J., 2004. Morphodynamic Behaviour and Sedimentary Variation of 933 Mixed Sand and Gravel Beaches, Suffolk, UK. Journal of Coastal Research 20, 256-276.

934 Pratt, R.M., Schlee, J., 1969. Glaciation on the Continental Margin off New England. Geol Soc America Bull 80, 2335-2342. https://doi.org/10.1130/0016-

937 Quick, M.C., Dyksterhuis, P., 1994. Cross-shore transport for beaches of mixed sand and gravel, 938 in: International Symposium: Waves_-Physical and Numerical Modeling. Canadian 939 Society of Civil Engineers. pp. 1443-1452.

940 Rădoane, M., Rădoane, N., Dumitriu, D., Miclăuş, C., 2008. Downstream variation in bed 941 sediment size along the East Carpathian rivers: evidence of the role of sediment sources.

942 Earth Surface Processes and Landforms 33, 674-694. https://doi.org/10.1002/esp.1568

943 Redfield, A.C., 1980. The tides of the waters of New England and New York. Woods Hole 944 Oceanographic Institution. 


\section{EarthArXiv preprint under review in Marine Geology}

945 Robinson, R.A.J., Slingerland, R.L., 1998. Origin of fluvial grain-size trends in a foreland basin; the Pocono Formation on the central Appalachian Basin. Journal of Sedimentary Research 68, 473-486. https://doi.org/10.2110/jsr.68.473

948 Sambrook-Smith, G.H., 1996. Bimodal fluvial bed sediments: origin, spatial extent and processes. Progress in Physical Geography 20, 402-417.

950

951

Sambrook-Smith, G.H., Feruson, R.I., 1995. The Gravel-Sand Transition Along River Channels. SEPM JSR A65, 423-430. https://doi.org/10.1306/D42680E0-2B26-11D7$8648000102 \mathrm{C} 1865 \mathrm{D}$

Sambrook-Smith, G.H., Nicholas, A.P., Ferguson, R.I., 1997. Measuring and defining bimodal sediments: Problems and implications. Water Resources Research 33, 1179-1185. https://doi.org/10.1029/97WR00365

Shaw, J., Kellerhals, R., 1982. The composition of recent alluvial gravels in Alberta river beds, Bull. 41, 151 pp. Alberta Research Council Bulletin 41, 151.

Shulmeister, J., Kirk, R.M., 1997. Holocene fluvial-coastal interactions on a mixed sand and sand and gravel beach system, North Canterbury, New Zealand. Catena 30, 337-355.

Stone, B.D., DiGiacomo-Cohen, M.L., 2006. Surficial geologic map of the PocassetProvincetown-Cuttyhunk-Nantucket 24-quadrangle area of Cape Cod and Islands, southeast Massachusetts (Open-File Report No. 2006-1260- E). United States Geological Survey.

Stone, B.D., Stone, J.R., 2019. Geologic origins of Cape Cod, Massachusetts; Guidebook for the Northeast Friends of the Pleistocene (Massachusetts Geological Survey Open-file Report No. 19-01). 


\section{EarthArXiv preprint under review in Marine Geology}

967 Stone, B.D., Stone, J.R., DiGiacomo-Cohen, M.L., 2006. Surficial geologic map of the Salem

968

969

970

971

972

973

974

975

976

977

978

979

980

981

982

983

984

985

986

987

988

989
Depot-Newburyport East-Wilmington-Rockport 16-quadrangle area in northeast Massachusetts (Open File Report No. 2006-1260- B). United States Geological Survey.

Stone, B.D., Stone, J.R., DiGiacomo-Cohen, M.L., Kincare, K.A., 2012. Surficial geologic map of the Norton-Manomet-Westport-Sconticut Neck 23-quadrangle area in southeast Massachusetts (No. Open-File Report 2006-1260-F). United States Geological Survey.

Stone, B.D., Stone, J.R., Masterson, J.P., O’Leary, D.W., 2004a. Integrating 3-D facies analysis of glacial aquifer systems with ground-water flow models: Examples from New England and the Great Lakes Region, USA (Open-file Series No. 2004-8). Illinois State Geological Survey.

Stone, B.D., Stone, J.R., McWeeney, L.J., 2004b. Where the glacier met the sea: Late Quaternary geology of the northeast coast of Massachusetts from Cape Ann to Salisbury, in: Proceedings of the New England Intercollegiate Geological Conference, Salem, Massachusetts, B-3. p. 25.

Stone, J.R., Stone, B.D., DiGiacomo-Dohen, M., L., Mabee, S.B., 2018. Surficial materials of Massachusetts-A 1:24,000-scale geologic map database. Scientific Investigations Map 3402. https://doi.org/10.3133/sim3402

Switzer, A.D., Pile, J., 2015. Grain size analysis, in: Shennan, I., Long, A.J., Horton, B.P. (Eds.), Handbook of Sea-Level Research. John Wiley \& Sons, Ltd., pp. 331-346.

Udden, J.A., 1914. Mechanical composition of clastic sediments. Bulletin of the Geological Society of America 25, 655-744. https://doi.org/doi:10.1130/GSAB-25-655

U.S. National Park Service, 2017. Physiographic Provinces - Geology [WWW Document]. URL https://www.nps.gov/subjects/geology/physiographic-provinces.htm (accessed 8.25.20). 
990 USACE, (U.S. Army Corps of Engineers), 2012. Nantasket Beach, Hull, MA Seawall Impacts on 991 Beach Erosion [WWW Document]. URL

992 https://www.yumpu.com/en/document/view/49940207/nantasket-beach-hull-ma-seawall993 impacts-on-beach-fsbpa (accessed 8.26.20).

994 Wentworth, C.K., 1922. A scale of grade and class terms for clastic sediments. The Journal of $995 \quad$ Geology 30, 377-392.

996 Wolcott, J., 1988. Nonfluvial Control of Bimodal Grain-Size Distributions in River-Bed Gravels. 997 SEPM JSR 58, 979-984. https://doi.org/10.1306/212F8ED6-2B24-11D7$998 \quad 8648000102 \mathrm{C} 1865 \mathrm{D}$

999 Wolman, M.G., 1954. A method of sampling coarse river-bed material. Eos, Transactions 1000 American Geophysical Union 35, 951-956. https://doi.org/10.1029/TR035i006p00951

1001 Woolf, D.K., Challenor, P.G., Cotton, P.D., 2002. Variability and predictability of the North 1002 Atlantic wave climate. Journal of Geophysical Research: Oceans 107, 9-1-9-14. $1003 \quad$ https://doi.org/10.1029/2001JC001124

1004 Zenkovich, V.P., 1967. Processes of coastal development. Oliver and Boyd, London.

1005 Zervas, C.E., 2009. Sea level variations of the United States, 1854-2006 (Technical Report No. $1006 \quad$ NOS CO-OPS 053). NOAA. 
Table 1. General characteristics of beaches, Massachusetts, USA

\begin{tabular}{|c|c|c|c|c|c|}
\hline Beach $^{1}$ & $\begin{array}{c}\text { Tide } \\
\text { Range (m) }\end{array}$ & $\begin{array}{c}\text { Average } \\
\text { Wave } \\
\text { Height }(\mathrm{m})^{2}\end{array}$ & $\begin{array}{c}\text { Wave Height } \\
\text { Standard } \\
\text { Dev. }(\mathrm{m})\end{array}$ & $\begin{array}{l}\text { Geomorphic } \\
\text { Setting }^{3}\end{array}$ & $\begin{array}{c}\text { Dominant } \\
\text { Source Material }^{4}\end{array}$ \\
\hline Salisbury & 2.7 & 0.9 & 0.3 & Inlet-Segmented & $\begin{array}{c}\text { Coarse Stratified } \\
\text { Deposits }\end{array}$ \\
\hline Plum Island & 2.7 & 0.9 & 0.3 & Inlet-Segmented & $\begin{array}{l}\text { Coarse Stratified } \\
\text { Deposits }\end{array}$ \\
\hline Rockport & 2.7 & 1.8 & 1.0 & Headland-Separated & Till \\
\hline Nahant & 2.8 & 0.8 & 0.2 & Headland-Separated & $\begin{array}{c}\text { Fine Stratified } \\
\text { Deposits }\end{array}$ \\
\hline Revere & 2.8 & 0.8 & 0.2 & Headland-Separated & $\begin{array}{l}\text { Fine Stratified } \\
\text { Deposits }\end{array}$ \\
\hline Nantasket & 2.8 & 0.8 & 0.2 & Headland-Separated & Till \\
\hline Peggotty & 2.7 & 0.9 & 0.6 & Headland-Separated & Mixed \\
\hline Humarock & 2.8 & 0.9 & 0.6 & Headland-Separated & Mixed \\
\hline Marshfield & 2.8 & 0.8 & 0.6 & Headland-Separated & Mixed \\
\hline Plymouth & 2.9 & 0.7 & 0.6 & Mainland-Segmented & $\begin{array}{l}\text { Coarse Stratified } \\
\text { Deposits }\end{array}$ \\
\hline Surf & 0.6 & 0.7 & 0.4 & Mainland-Segmented & Mixed \\
\hline Low & 0.9 & 1.8 & 0.9 & Mainland-Segmented & $\begin{array}{l}\text { Coarse Stratified } \\
\text { Deposits }\end{array}$ \\
\hline Miacomet & 0.9 & 1.7 & 0.8 & Mainland-Segmented & $\begin{array}{l}\text { Coarse Stratified } \\
\text { Deposits }\end{array}$ \\
\hline Town & 0.6 & 0.6 & 0.3 & Mainland-Segmented & Mixed \\
\hline Sylvia & 0.6 & 0.6 & 0.3 & Mainland-Segmented & Mixed \\
\hline Barges & 1.0 & 1.2 & 0.6 & Headland-Separated & Till \\
\hline East & 1.1 & 1.2 & 0.6 & Headland-Separated & Till \\
\hline Horseneck & 1.1 & 1.2 & 0.6 & Headland-Separated & Till \\
\hline
\end{tabular}

${ }^{1}$ Study sites at Rockport, Nahant, and Plymouth are referred to colloquially as "Long Beach." The study site at Marshfield aggregates the coast between Rexhame Beach and Brant Rock and includes Fieldston Beach. We instead refer to these by their respective municipalities.

${ }^{2}$ Average significant wave heights along with standard deviations for the 18 sites over model simulations for years 2014 through 2016 where simulations are available every hour over this interval; data taken from nearest deep-water grid cell (i.e. depth>Lo/2)(Warner and others, 2010).

${ }^{3}$ From FitzGerald and van Heteran, (1999).

${ }^{4}$ Coarse stratified deposits = glacial outwash, delta deposits; fine stratified deposits $=$ fine-grained glacial marine sediments; till $=$ derived from ground moraine or erosion of drumlins; mixed $=$ combination of two source materials, glacial till and coarse stratified deposits in various proportions. 


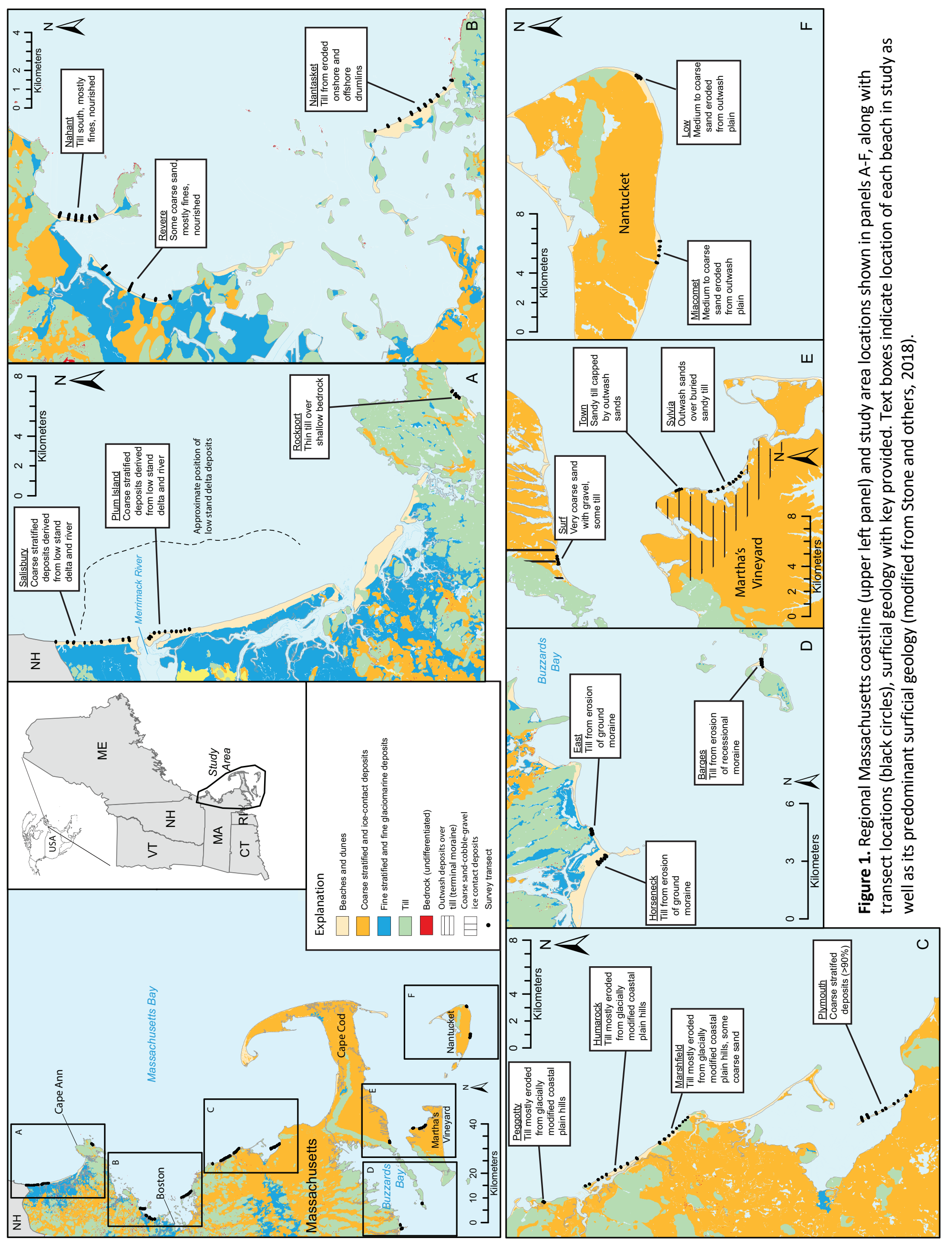



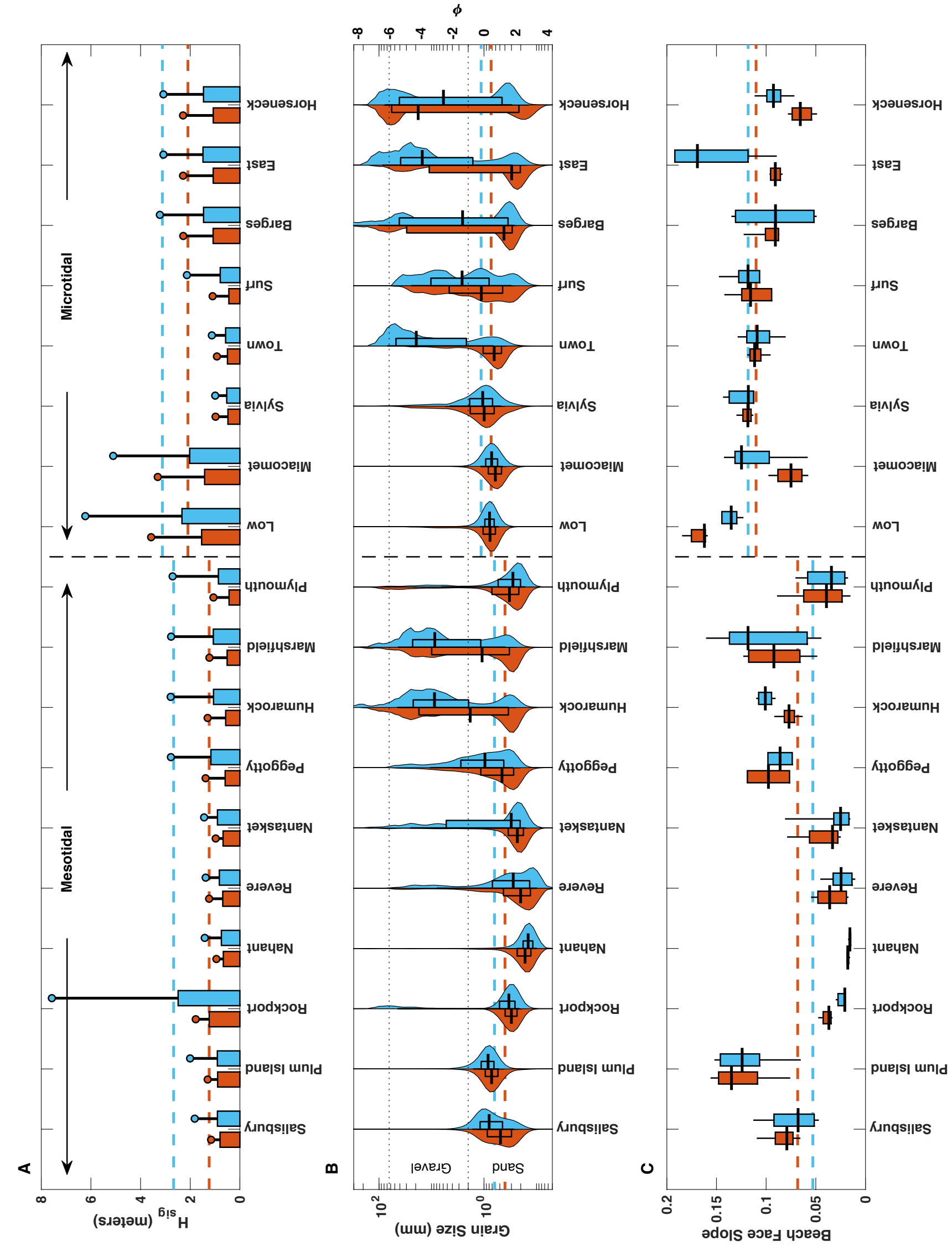

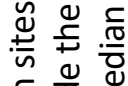

듀음

Ф) 듬

vi 0

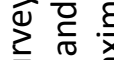

ज

엄 드 흐

으음 김

过 승

उ

ర들

ठิ

0

등 운 은

히 은 히

है है

宅

ㅎํㅇ

돌

으 든 式

는 는 은

○

능 힝

ब

은 뜬 원

ज 늠

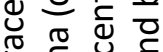

ह त

约 文 ญ

ه ह ᄃ ᄃ

잉 की

잉 운

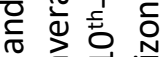

(1) त 군

츤 으으

당 त

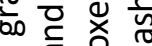

응 응

जั

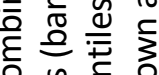

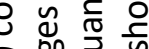

m

을 ญ 잉 음

ธิ

II.

1 的

둘 흘 을

ปิ

들 을

ญ

了兵梪

芒苛 穴

는 소

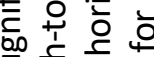

的立 浖

宅을 읃

i

บ 


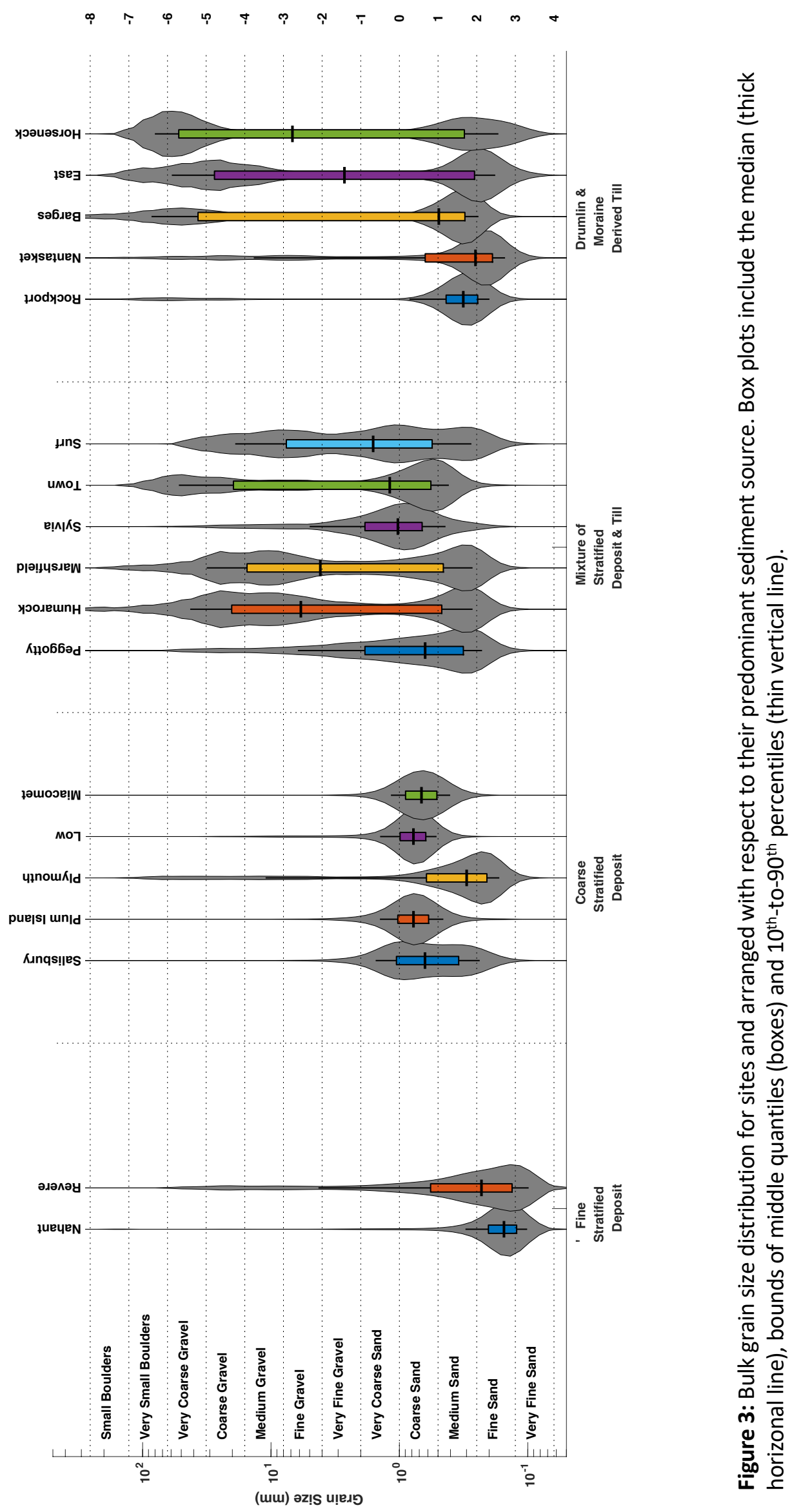




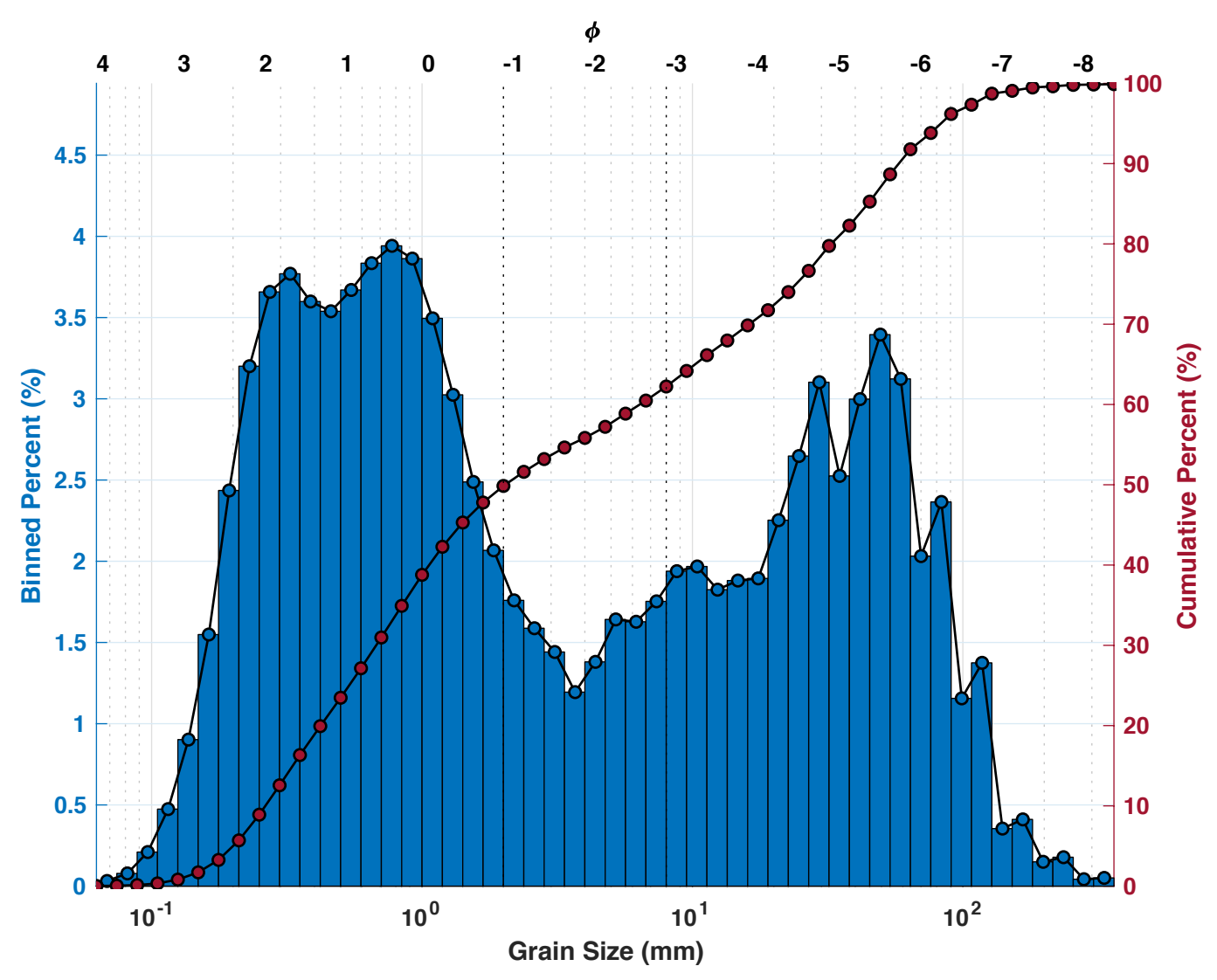

Figure 4: Composite grain size distribution of binned (blue) and cumulative (red) percent for all intertidal mixed sand and gravel samples (MSG). Here MSG samples are defined as greater than $5 \%$ of distribution exceeding $2 \mathrm{~mm}(\mathrm{n}=454)$. 

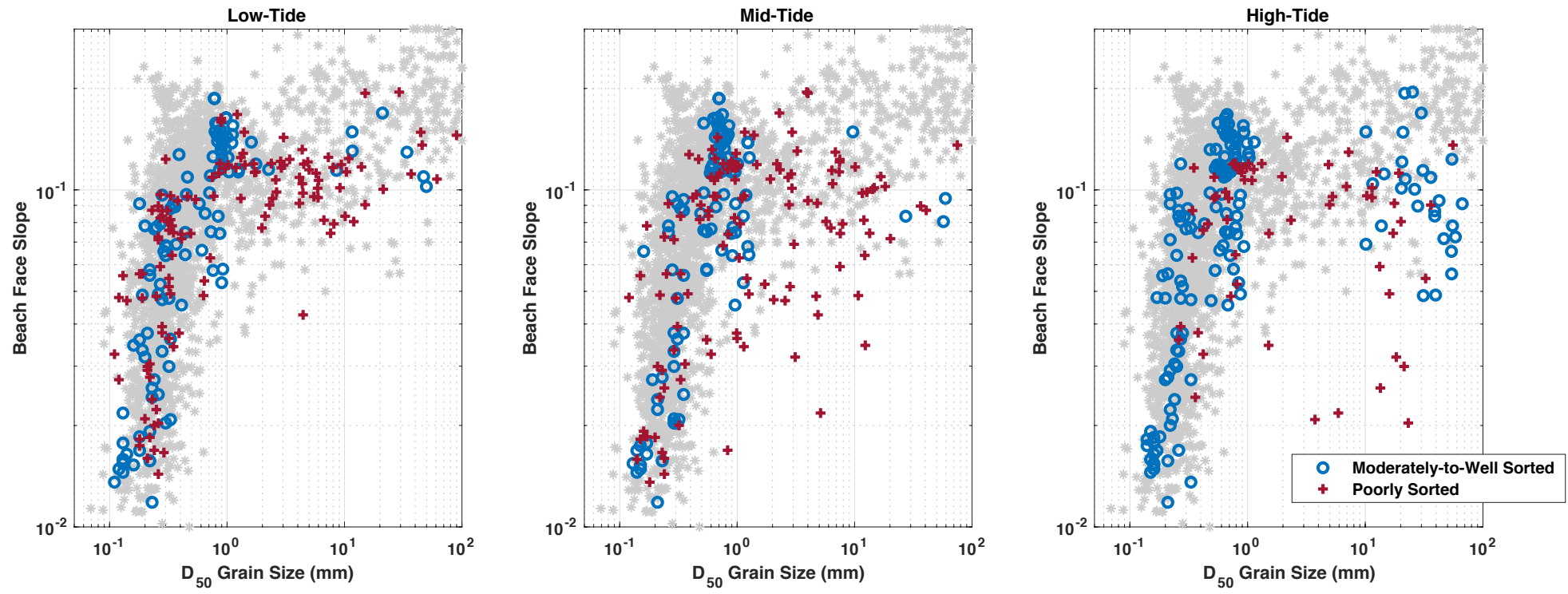

Figure 5: Median $\left(D_{50}\right)$ grain size versus beach face slope for low tide (left panel), mid tide (middle panel) and high tide (right panel) compared to the global data set of Bujan et al. (2019). Moderately-to-well sorted samples (circles) and poorly sorted samples (plus markers) are defined by criteria presented by Blott and Pye (2001). The same global data set from Bujan et al. (2019) is shown in each panel (gray asterisk) where grain sizes represents either a $D_{50}$ or mean and were obtained by a variety of methods provided by references therein. 

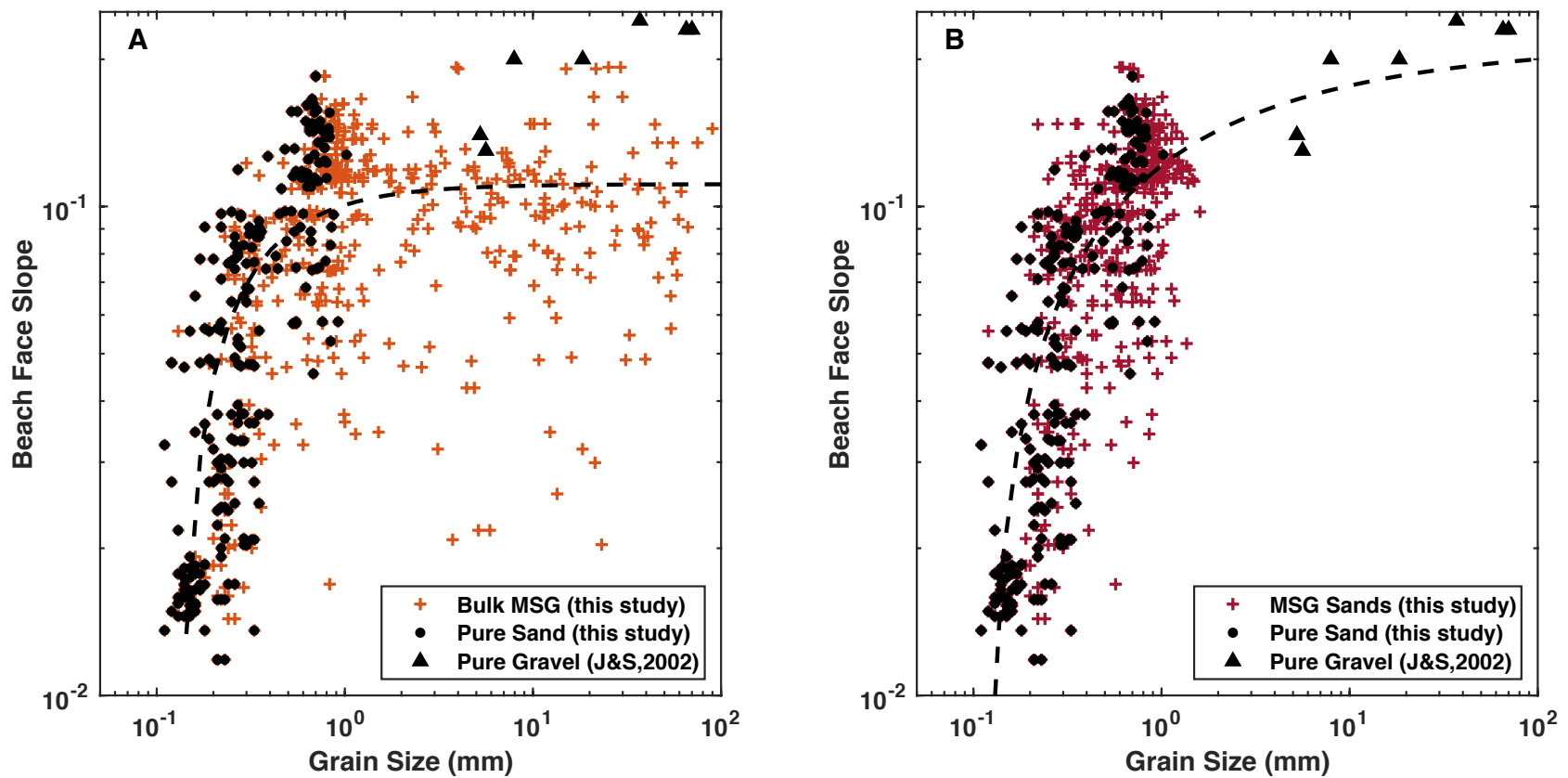

Figure 6: (A) Median grain size versus beach face slope for MSG (plus signs) and pure sand beaches (black circles) in this study compared to data by Jennings and Schulmeister (2002) for pure gravel beaches (J\&S,2002, black triangles). Left panel is bulk $D_{50}$ grain size and right panel is the median grain size of just the isolated sand fraction (i.e. median for distribution $<2 \mathrm{~mm}$ ). Power law fits (dashed lines) are provided for bulk $\mathrm{D}_{50}$ and median size in sand fraction $\left(\mathrm{Ds}_{50}\right)$ versus beach face slope $(S)$. Values of best fit for right panel in the form of $\mathrm{S}=\mathrm{a} * \mathrm{Ds}_{50} \wedge \mathrm{b}+\mathrm{c}$ and fitted parameters of $\mathrm{a}=-0.10, \mathrm{~b}=-0.37$, and $\mathrm{c}=0.22$. 

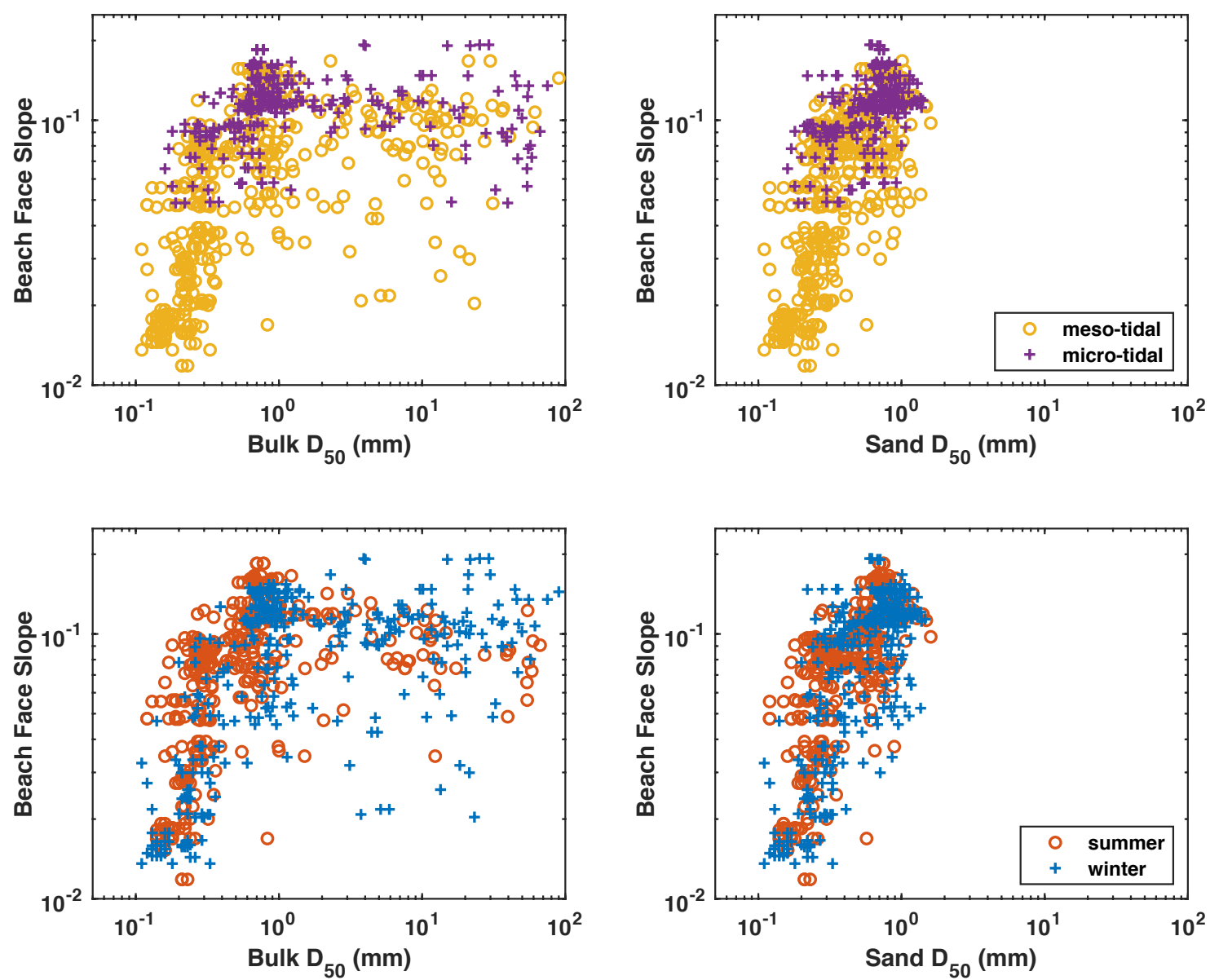

Figure 7: Beach face slope versus bulk median grain size (left panels) and median grain size for sand fraction (right panels) categorized by tidal region (top panels) and season (bottom panels). 